\title{
A REVIEW OF PHOSPHORUS AND SEDIMENT RELEASE FROM IRISH TILLAGE SOILS, THE METHODS USED TO QUANTIFY LOSSES AND THE CURRENT STATE OF MITIGATION PRACTICE
}

\author{
J.T. Regan, O. Fenton and M.G. Healy
}

J.T. Regan and M.G. Healy (corresponding author; email: mark. healy@nuigalway.ie), Department of Civil Engineering, National University of Ireland, Galway; O. Fenton, Teagasc, Johnstown Castle, Environmental Research Centre, Co. Wexford.

Cite as follows: Regan J.T., Fenton, O. and M.G. Healy 2011 A review of phosphorus and sediment release from Irish tillage soils, the methods used to quanify losses and the current state of mitigation practice. Biology and Environment: Proceedings of the Royal Irish Academy 112B.

DOI: 10.3318/

BIOE.2012.05.

Received 26 October 2010. Accepted 19 October 2011. Published 20 March 2012.

\begin{abstract}
Throughout the European Union (EU), agricultural soils with high phosphorus (P) status due to surplus fertiliser input have been identified as a landscape pressure impacting on water quality. In Republic of Ireland, approximately $80 \%$ of agricultural land is devoted to grass, $11 \%$ to rough grazing, and $9 \%$ to arable cereal and crop production. Consequently, the majority of erosion research has focused on quantifying nutrient and sediment losses from grassland. Tillage soils are, however, more susceptible to erosion than grassland soils and, in general, have higher levels of soil P. This paper reviews the current state of research and the regulatory regime relating to diffuse $\mathrm{P}$ and sediment loss for tillage soils. It identifies the key threats to soil quality associated with cultivated soils, and proposes the targeting and remediation of critical source areas for effective mitigation of $\mathrm{P}$ losses from tillage soils. A multiscaled approach is recommended, in which catchment and field-scale monitoring is complemented with controlled laboratory and small plot-scale rainfall simulation experiments to identify areas where $\mathrm{P}$ loss and soil erosion are at critical levels and may pose a threat to water quality. Catchment scale research will help to link critical source areas of sediment and P loss with hydrological pathways to surface waters in the catchment area. These areas can then be targeted for remediation in the river basin management plans.
\end{abstract}

\section{INTRODUCTION}

Currently in Ireland, the extent of erosion and phosphorus $(\mathrm{P})$ loss from tillage land is unknown, as research has concentrated on quantifying losses from the more dominant grassland. Increasing eutrophication of many surface water bodies in arable regions of the UK has been linked with increasing rates of soil erosion causing sediment and P loss from fields cropped with winter cereals and with an accumulation of soil $\mathrm{P}$ through continuous application of fertiliser and manures (Catt et al. 1998). Research to establish the circumstances leading to sediment and P losses from arable land and to quantify these losses has been carried out in the UK (Speirs and Frost 1987; Chambers et al. 1992; Catt et al. 1998; Chambers and Garwood 2000) and throughout Europe (Kronvang et al. 1997; Verstraeten and Poesen 2001; Miller and Quinton 2009) at multiple scales. Reported sediment and P losses from arable sites in these and other similar studies were significantly higher than losses from grassland, and were high enough to cause concern over the eutrophication of surface water bodies in arable areas. Further research to evaluate the effectiveness of well-established mitigation options for the prevention of soil erosion and reduction of $\mathrm{P}$ loss from arable land was carried out in studies by Chambers et al. (2000), Koskiaho (2002), Quinton and Catt (2004), Ulén and Jakobsson (2005), Kronvang et al. (2005), Knappen et al. (2008), Deacy et al. (2009), Stevens et al. (2009) and Silgram et al. (2010).

Diffuse $\mathrm{P}$ loss from arable land can be as high as $1-2 \mathrm{~kg} \mathrm{P} \mathrm{ha} \mathrm{Pear}^{-1}$ in the northern temperate zone, especially in areas with widespread soil erosion (Ulén et al. 1991). This review determines the current state of research on diffuse $\mathrm{P}$ and sediment losses relating to tillage soils in Ireland. It examines the associated key threats to soil and water quality and identifies knowledge gaps and future needs in erosion research on Irish tillage soils. 
AGRICULTURE AND WATER QUALITY IN IRELAND

In the Republic of Ireland, agriculture accounts for $60.8 \%$ (approx. 4.2 million ha) of the total land area (CSO 2010), well above the European average of approximately $40 \%$. Of this agricultural land, approximately $80 \%$ is devoted to grass (silage, hay and pasture), 11\% to rough grazing, and $9 \%$ to arable cereal and crop production, with barley as the most important cereal crop representing $4.4 \%(185,900 \mathrm{ha})$. Most of the grain is used for the production of animal concentrated feedstuffs. Forty-eight per cent of crop production is concentrated in the south of the country (Schulte et al. 2010a), where the soils are highly suitable for tillage, having a light-to-medium texture and free drainage (Gardiner and Radford 1980). In the southeast, cereals alone account for $17 \%$ of farmed land in County Carlow and $23 \%$ in County Wexford (Hooker et al. 2008). In the south of the country, and the southeast in particular, the favourable climate provides better opportunities for seedbed preparation and harvesting. There are fewer wet days, higher temperatures, lower chances of frost, higher radiation receipts and more hours of bright sunshine (Collins and Cummins 1996).

While tillage land (cereals and root crops) accounts for a relatively small area- $9.6 \%$ of agricultural area utilised in the Republic of Ireland (CSO 2010) - it accounts for a lot of the high $\mathrm{P}$ status soils due to higher fertilisation rates on tillage land. It may therefore make a disproportionate contribution to the total $\mathrm{P}$ input to surface water systems from agricultural soils. Mean P fertiliser use in the Republic of Ireland for cereals and root crops $(<10 \%$ of tillage area) in 2008 was $20 \mathrm{~kg} \mathrm{ha}^{-1}$ and $46 \mathrm{~kg} \mathrm{ha}^{-1}$, respectively, while P fertiliser use for grassland was only $5 \mathrm{~kg} \mathrm{ha}^{-1}$ (Lalor et al. 2010). These figures highlight the potential for higher P losses in surface runoff from tillage land than from grassland. For good water quality in Irish water bodies, it is considered that $\mathrm{P}$ additions from all sources should not give rise to a concentration $>0.035 \mathrm{mg} \mathrm{l}^{-1}$ (Bowman 2009). To date, arable land in Ireland has received limited attention for its potential to impact on water quality (Doody et al. 2012).

Continual fertiliser application at high rates on agricultural land in the past resulted in excessive levels of plant-available $\mathrm{P}$ in soils (Tunney 2000). Excess P may then be available to surface runoff following heavy rainfall events (Culleton et al. 2002). As soil $\mathrm{P}$ increases, $\mathrm{P}$ loss in surface runoff and subsurface flow increases (Sharpley et al. 2001b). Therefore, the higher the Morgan's
$\mathrm{P}\left(\mathrm{P}_{\mathrm{m}}\right.$; the national soil $\mathrm{P}$ test in the Republic of Ireland for determining plant-available P) level in the fields of a catchment area, the greater the risk of high concentrations of in-stream $\mathrm{P}$ during wet months (Lewis 2003). Previous grassland studies at plot (Pote et al. 1999) and field (Tunney et al. 2000) scale have shown that there is a positive relationship between the $\mathrm{P}_{\mathrm{m}}$ level in soils and dissolved reactive phosphorus (DRP) lost in surface runoff.

Excessive manure and fertiliser application is not only wasteful, but can lead to a build-up of $\mathrm{P}$ in excess of crop requirements in the soil. The excess $\mathrm{P}$ may then be mobilised by surface runoff during periods of heavy rainfall. The United States Department of Agriculture estimates that about half the fertiliser used each year in the United States simply replaces soil nutrients lost by topsoil erosion (Montgomery 2007). Soil test phosphorus (STP), accumulated to very high concentrations, can take up to twenty years of continual crop harvesting with no addition of $\mathrm{P}$ from any source to reduce to concentrations normally recommended for agronomic production and to pose no threat to surface water quality (Sharpley and Rekolainen 1997).

In the Republic of Ireland, Morgan's extractant (Peech and English 1944) is currently used to match $\mathrm{P}$ fertiliser recommendations with crop requirements. Fertiliser advice is modified for some tillage crops, according to crop yields, soil texture or expected summer rainfall (Coulter and Lalor 2008). P advice for grassland and tillage crops in the Republic of Ireland is based on a four-category soil P-index system (Table 1). The basis of this system is a set of soil indices based on the measured $\mathrm{P}_{\mathrm{m}}$ in the soil and the crop's response to fertiliser application, as measured by field experimentation. For tillage soils in $\mathrm{P}$ index 4 , the addition of $\mathrm{P}$ is prohibited, with the exception of soils planted with potatoes, beet and turnips. Schulte et al. (2010a) developed a model of STP decline on eight principal soil series/ associations representative of a range of STP concentrations for grassland in Ireland. They found that where the $\mathrm{P}_{\mathrm{m}}$ was at $28 \mathrm{mg} \mathrm{l}^{-1}$, with no further $\mathrm{P}$ inputs (estimated to be equivalent to an annual field P-balance deficit of $30 \mathrm{~kg} \mathrm{ha}^{-1}$ year $^{-1}$ ) it took from seven to fifteen years for a soil to move from index 4 to index 3 (Table 1).

The current agronomic optimum $\mathrm{P}_{\mathrm{m}}$ value for Irish soils is $6 \mathrm{mg} \mathrm{l}^{-1}$ for grass production (Daly et al. 2001). In Ireland, low soil $\mathrm{P}_{\mathrm{m}}$ concentrations of $1 \mathrm{mg}^{-1}$ in the 1950 s severely limited crop production. Although national sales of $\mathrm{P}$ fertiliser have fallen from $62,410 \mathrm{t}$ year $^{-1}$ to 26,350 t year ${ }^{-1}$ during the 1995 to 2008 period (DAFF 
Table 1-Phosphorus index system (from S.I. No. 610 of 2010 and adapted from Schulte et al. 2010a).

\begin{tabular}{lccl}
\hline Soil $P$ & \multicolumn{2}{c}{ Soil P ranges $(\mathrm{mg} / \mathrm{l})$} & \\
\cline { 2 - 3 } Index & Grassland & Tillage & \\
\hline 1 & $0.0-3.0$ & $0.0-3.0$ & Soil is phosphorus $(\mathrm{P})$ deficient: build-up of soil P required \\
2 & $3.1-5.0$ & $3.1-6.0$ & Low soil P status: build-up of soil P is required for productive agriculture \\
3 & $5.1-8.0$ & $6.1-10.0$ & Target soil P status: only maintenance rates of P required \\
4 & $>8.0$ & $>10.0$ & Excess soil P status: no agronomic response to P applications \\
\hline
\end{tabular}

2009b) - primarily due to new farming practices, implementation of the Nitrates Directive (91/676/ EEC: Council of the European Union 1991) and rising fertiliser costs-the mean $\mathrm{P}_{\mathrm{m}}$ concentration in Irish soils is currently $8 \mathrm{mg} \mathrm{l}^{-1}$ (Daly et al. 2001). Maintenance of the P fertility of arable soils is important, as cereal crops perform better in soils with good $\mathrm{P}$ status $\left(6.1-10.0 \mathrm{mg}^{-1}\right.$ Morgan's P) than in soils with low $\mathrm{P}$ status that have been supplemented with higher levels of $\mathrm{P}$ fertilisers (Schulte et al. 2010b).

Tillage land has higher $\mathrm{P}$ application rates than grassland due to the higher off-takes and the need for new seeding each year. Sufficiently high available-P levels are needed for satisfactory seed germination. Advice given to farmers on $\mathrm{P}$ application for cereal crops is based on maintaining the STP at the optimum agronomic level of index 3 (Table 1). This is achieved by applying enough $\mathrm{P}$ to replace the anticipated crop off-take (a grain yield of 1 tonne $\mathrm{ha}^{-1}=$ an off-take of $\left.3.8 \mathrm{~kg} \mathrm{P} \mathrm{ha}^{-1}\right)$, based on the expected yield of the crop to be fertilised (Coulter and Lalor 2008). Where proof of higher yield is available, an additional $3.8 \mathrm{~kg} \mathrm{P} \mathrm{ha}^{-1}$ can be applied on soils at $\mathrm{P}$ indices 1, 2 and 3 for each additional tonne above a threshold crop yield, dependant on crop variety (S.I. No. 610 of 2010). Where the soil index is below 3, build-up levels are necessary in addition to anticipated crop off-take in order to raise the soil to index 3 . Regular soil testing should be carried out to ensure that soils are kept within the agronomic optimum soil index. Root crops, like potatoes and fodder beet, are very responsive to $P$ and it is necessary to apply $\mathrm{P}$ (when sowing), even at index 4 , to achieve the agronomic optimum.

The impact of land use (agriculture) and soil characteristics (parent material and wetness) on plant-available $\mathrm{P}$ distribution in soils is given credence by Zhang et al. (2008) in a geochemical mapping study of Ireland. Here, $\mathrm{P}_{\mathrm{m}}$ was measured in 1310 surface $(0-10 \mathrm{~cm})$ soil samples collected from predetermined positions at a density of two samples per $100 \mathrm{~km}^{2}$ based on an unbiased grid sampling scheme. Zhang et al. delineated the areas having high available $\mathrm{P}$, using the index bands for tillage soils in the $P$ index system (Table 1), which state that soils having levels above $10 \mathrm{mg} \mathrm{l}^{-1} \mathrm{P}_{\mathrm{m}}$ are in excess of crop requirement. The authors attributed high levels of available P in County Louth, east Dublin and southeast Wexford to a combination of lighttextured soils, and vegetable and tillage farming in these areas. Similarly, in northwest Kerry, tillage farming on light-textured soils results in elevated $\mathrm{P}$ levels. Furthermore, high $\mathrm{P}$ levels in east and central Cork were attributed to a combination of intensive dairying and tillage on highly fertile soils, while high levels in north Carlow and south Kildare may be due to intensive tillage on limestone-derived soils. Reducing these soil P levels may not be possible in the short term, as Schulte et al. (2010a) showed that elevated soil P concentrations resulting from agricultural land use may take many years to be reduced to agronomically and environmentally optimum levels.

A biological survey of $13,188 \mathrm{~km}$ of Irish river and stream channels from 2007 to 2009 (McGarrigle et al. 2010) estimated that 20.7\% were slightly polluted, $10 \%$ were moderately polluted and $0.4 \%$ were seriously polluted. When assessed for ecological status according to the requirements of the Water Framework Directive (WFD; 2000/60/EC: Council of the European Union 2000), based on the various biological and supporting physicochemical quality elements for individual river water bodies on a one-out all-out basis, a different picture emerges. Just $52 \%$ of the water bodies achieved 'good status' $\left(<0.035 \mathrm{mg} \mathrm{P}^{-1}\right.$ in rivers) (McGarrigle et al. 2010). Of the 2515 sites surveyed in this period, the percentage of pollution attributed to agriculture was approximately $54 \%$ and $39 \%$ in rivers and streams that were slightly or moderately polluted, respectively. Agriculture only contributed $15 \%$ of pollution, however, in those water bodies that were seriously polluted. These data indicate that diffuse agricultural pollution causing eutrophication accounted for $47 \%$ of the polluted river 
sites recorded over this period. Diffuse losses from agriculture were reported by McGarrigle and Donnelley (2003) to account for 59\% of total phosphorus (TP) exported from a rural Irish catchment. Almost half the rivers sampled in 2008 for phosphates in the South Eastern River Basin District (SERBD), where tillage is common, would not achieve good status based on this nutrient (Lucey et al. 2009). All lakes assessed from 2007 to 2009 in the SERBD were of moderate or poor ecological status, largely due to TP and chlorophyll possibly related to intensive agriculture (McGarrigle et al. 2010).

\section{LEGISLATIVE BACKGROUND}

The WFD aims to restore polluted water bodies to 'at least' good ecological and chemical status ( $<0.035 \mathrm{mg} \mathrm{P}^{-1}$ in rivers) by 2015 and prevent any further deterioration in the status of surface waters, transitional waters, groundwater and water-dependent terrestrial ecosystems and wetlands. Key to the WFD is the adoption and implementation of river basin management plans (RBMPs) and programmes of measures (POMs) by the end of 2012. These set out the actions required within each major river basin to achieve set environmental quality objectives, which will be reviewed on a six-yearly basis. These plans must include basic measures and, where necessary, supplementary measures to be implemented for a specific water body to help achieve prescribed water quality standards. The RBMPs have identified agriculture as one of the main physico-chemical pressures affecting a waterbody. The basic regulation for agriculture in the Republic of Ireland is the Nitrates Directive and this is given statutory effect in the European Communities (Good Agricultural Practice for Protection of Waters) Regulations 2010 (S.I. No. 610 of 2010). The latter regulation sets out detailed nutrient management controls for farming, including $\mathrm{P}$ application rates for crop production.

Implicit in these directives and management plans is the protection and preservation of soils. An EU Draft Soil Framework Directive (SFD; COM (2006) 231: Commission of the European Communities 2006) identifies the following threats to soil quality: erosion, decline of soil organic carbon (SOC), compaction, contamination, sealing, salinisation, landslides and desertification. To date, however, the directive has not been ratified. If ratified, Member States will have to identify areas where soil degradation processes have occurred or are likely to occur in the future. The identification of areas at risk of erosion will take account of the following parameters:

- soil type;

- texture and density;

- hydraulic properties;

- topography (including slope gradient and length);

- land cover and use;

- climate (including rainfall distribution and wind characteristics);

- hydrological conditions; and

- agro-ecological zones.

Once risk areas have been identified, Member States will be required to draw up POMs, including a timetable for implementation. Ratification of the SFD will result in the unification of soil measures in one directive and provide a common approach and level playing field for Member States with regard to soil protection (Creamer et al. 2010).

\section{RESEARCH TO DATE ON SEDIMENT AND P LOSS}

Until now, the majority of research in Ireland has focused on quantifying nutrient and, to a lesser extent, sediment losses from permanent grassland at laboratory- (Doody et al. 2006; Murphy 2007; Murphy and Stevens 2010), plot/field- (Tunney et al. 2007; Kurz et al. 2000; 2005; 2006; Douglas et al. 2007) and catchment-scales (Smith et al. 1995; Scanlon et al. 2004; Jordan et al. 2005a; 2005b; Smith et al. 2005; Jordan et al. 2007). Modelling of diffuse $\mathrm{P}$ loss from grassland catchments has also been undertaken by Jordan et al. (2000), Daly et al. (2002), Scanlon et al. (2005) and Nasr et al. (2007), with the aim of improving management strategies to minimise $\mathrm{P}$ loss. Tillage soils are, however, more susceptible to water erosion than grassland soils (Van Oost et al. 2009) due to greater soil surface exposure to erosive forces during fallow and planting periods (Lal 2001) and soil disturbance by tillage operations (Lal 2001), which alters its structure. Furthermore, in grassland soils, higher infiltration rates can lower runoff rates (Fullen 1991) and higher organic matter levels can reduce erodibility (Fullen 1998).

In an analysis of studies investigating the relationship between dissolved phosphorus (DP) concentration in runoff and STP, Sibbesen and Sharpley (1997) noted that for the same level of STP, generally less P was lost from grassland than from cultivated land. This may result from less interaction of the surface runoff with surface soil for grass than for tillage crops due to better vegetative cover and surface-soil protection by 
grass (Sharpley 1995). Disturbance of soil structure by tillage operations also increases aggregate dispersion and the degree of interaction between soil and runoff water, thereby enabling more DP to be mobilised from soils with high P (Sharpley et al. 2001a). Given the susceptibility of tillage land to erosion in general and high $\mathrm{P}$ applications associated with this land use in Ireland, there is a need to quantify the $\mathrm{P}$ and sediment losses from tillage soils to surface water bodies and monitor the effects of improving tillage practices.

\section{FACTORS AFFECTING SOIL}

\section{EROSION RATES IN IRELAND}

Very few studies in Ireland have looked at soil erosion rates on tillage soils, despite international research by Kronvang et al. (1997), Chambers et al. (2000), Deasy et al. (2009), Stevens et al. (2009) and Van Oost et al. (2009) concentrating specifically on such soils due to their erosion propensity. The loss of fertile topsoil due to soil erosion on agricultural land is a growing problem in Western Europe, and has been identified as a threat to soil quality and the ability of soils to provide environmental services (Boardman et al. 2009). Greater demand for food and advances in farm machinery has resulted in intensified crop production, leading to increased soil compaction and higher tillage and water erosion rates. Lindstrom et al. (2001) defined tillage erosion as 'the net movement of soil downslope through the action of mechanical implements'. Both types of erosion can have a negative impact on productivity, with the most severe impact occurring due to a loss of topsoil depth in soils with a root restrictive layer (Lal 2001). It is estimated that 115 million ha, or $12 \%$ of Europe's total land area, is affected by water erosion (EEA 1995). Soil water erosion in the UK is primarily a regional phenomenon, associated with sandy tillage soils in the southwest and southeast of England (Chambers et al. 2000). In Ireland, soil erosion is primarily a phenomenon associated with tillage soils and periods of intense rainfall (Fay et al. 2002). The potato-growing area of Donegal is a good example of such an area. The main drivers predisposing arable soils to water erosion in Ireland and the UK are: soil type, precipitation (amount, duration and intensity), and management practice.

\section{SOIL TYPE}

Soil type is important when determining the erosion risk from an arable field. The texture of a soil strongly influences soil organic matter (SOM) storage (Fullen et al. 2006). Soil organic matter breaks down faster in sandy soils than in fine-textured soils due to:
- a lack of clay for physico-chemical binding with SOM (Fullen et al. 2006); and

- greater oxygen availability for decomposition by microorganisms in the clay.

Disturbance of topsoil by tillage operations further aerates the soil which, in turn, increases soil SOM decomposition. Fullen et al. (2006) also reported that silt can play an important role in influencing organic matter storage in clay-deficient sandy soils. Sandy soils are particularly vulnerable to erosion due to low SOM content and poor structural stability, which predisposes the soil to disaggregation under raindrop impact and a subsequent development of a surface crust, reduction of infiltration rate and surface runoff (Quinton and Catt 2004). Long-term arable use and modern cultivation methods can result in light textured soils capping (a surface crust caused by heavy raindrops on finely cultivated soils) under rain impact (Fraser et al. 1999). In a review of critical levels of SOC in tillage land in Ireland, Spink et al. (2010) concluded that soil function is unlikely to be adversely affected when SOC is above a threshold of $2 \%$ (equivalent to $3.4 \% \mathrm{SOM}$ ). Soils with less SOM than this threshold should be further assessed to see whether they are in good environmental and agronomic condition. These further measures could include observation of: erosion; gullies in the field; compaction; and capping (Spink et al. 2010).

Increasing SOM content improves the cohesiveness of the soil, reduces the risk of surface crusting, lowers the risk of soil compaction, increases its water holding capacity and promotes soil aggregate formation, thereby improving structural stability and reducing erosion. As an EU Member State, Ireland is required to monitor SOC levels in long-term (6 years or more) tillage soils in order to ensure that sustainable management practices are put in place to reduce any further decline in SOC (DAFF 2009a). In contrast to the UK, no work has yet been carried out in Ireland to determine the susceptibility of sandy soils to erosion under arable cropping. Findings in the UK may be indicative of potential erosion problems with sandy tillage soils in Ireland, but there is a need for Irish-specific data to establish whether there is an erosion problem.

\section{PRECIPITATION (AMOUNT, DURATION AND INTENSITY)}

Rainfall characteristics influence the processes affecting infiltration, runoff, soil detachment and sediment and chemical transport (Truman 2007). The risk of nutrient loss is generally greatest when soils are near field capacity or saturation, and any 
further precipitation leads to water surpluses and either subsurface drainage or overland flow (Schulte et al. 2006a). In unsaturated soils, erosion and $\mathrm{P}$ loss is mainly governed by the occurrence, frequency and timing of intense storm events that result in powerful overland flow events. Rainfall intensity is generally considered to be one of the most important factors influencing soil erosion by overland flow in rills, because it affects the detachment of soil particles by raindrop impact and enhances their transport by runoff.

A study by Chambers et al. (2000) of thirteen erosion-susceptible arable catchments (containing medium silt, sand/light loam, silty clay loam, loamy sand and sandy loam soils) in England and Wales between 1989 and 1994 revealed that soil erosion can occur at any time of the year, provided the conditions suitable for erosion are present. These include:

- lack of ground cover vegetation $(<15 \%)$;

- loose, fluffy and very fine seed-bed conditions;

- heavy rainfall $\left(>15 \mathrm{~mm} \mathrm{day}^{-1}\right)$ with a high intensity $\left(>4 \mathrm{~mm} \mathrm{~h}^{-1}\right)$ in the presence of high winds;

- steep slopes;

- presence of valley floor features that concentrate surface runoff; and

- compacted tramlines (unseeded wheeling areas used to facilitate spraying operations in cereal crops).

The incidence of severe erosion resulting in transport of suspended sediment (SS) and P, in particular, tends to be highly dependent on hydrological storm events (Edwards and Withers 2008). It has been shown that approximately $90-95 \%$ of soil erosion occurs during the most severe $2 \%$ of storms (Winegardner 1996). Erosion also occurs over periods of prolonged lower-intensity rainfall (Fraser et al. 1999; Robinson 1999).

Mean annual precipitation for Ireland ranges from $750-1000 \mathrm{~mm}$ on the eastern half of the country to $1000-1400 \mathrm{~mm}$ on the western half (Met Éireann 2012). The highest annual rainfall of between $1600 \mathrm{~mm}$ and $2800 \mathrm{~mm}$ occurs when Atlantic rain-bearing storms encounter landfall and mountainous terrain on the west coast. Any change in precipitation (amount, duration and intensity) over Ireland as a result of climate change is likely to have a direct impact on $\mathrm{P}$ and sediment losses in surface runoff from agricultural soils. The ten-year moving average for Ireland shows that rainfall amounts increased from $800 \mathrm{~mm}$ in the $1890 \mathrm{~s}$ to $1100 \mathrm{~mm}$ in the $1990 \mathrm{~s}$ (McElwain and Sweeney 2006).

The general consensus from numerous climate change studies in Ireland is that winter rainfall will increase, as will the frequency of intense rainfall events during summer. An Environmental Protection Agency (EPA) report by Sweeney et al. (2008) on the impacts of climate change for Ireland projected an increase in winter rainfall of $10 \%$ by 2050 . Summer rainfall reductions of $12-17 \%$ are projected to occur by this time. Spatially, the largest percentage winter increases are forecast for the midlands, while summer reductions of $20-28 \%$ are forecast for the southern and eastern coasts. Sweeney et al. (2008) also predicted more frequent intense rainfall events during the summer. Increased $\mathrm{P}$ export in summer, resulting from high-intensity rainfall events has been reported in numerous Irish grassland studies by Lennox et al. (1997), Tunney et al. (2000), Kurz (2000), Morgan et al. (2000), Kiely (2000) and Irvine et al. (2001). Overland flow events resulting from intense summer rainfalls could potentially transport $\mathrm{P}$ and sediment from vulnerable tillage soils to surface water bodies during the growing season.

\section{MANAGEMENT PRACTICES}

Erosion driven by management practices, such as the decisions made by farmers as to what crops to grow, how to manage and prepare the land, and when to sow, are also very important and easier to change in the short term. Research on cultivation practice in the UK by Chambers and Garwood (2000) identified valley features, lack of crop cover, wheelings (the passage over soil by wheels of a vehicle) and tramlines as the main contributors to erosion. Research by Silgram et al. (2010) on sandy loam and silty clay loam soils on $4^{\circ}$ slopes in England has shown that tramlines can represent the most important pathway for $\mathrm{P}$ and sediment loss from moderately sloping fields. In a study of mitigation options for sediment and $\mathrm{P}$ loss from winter-sown arable crops on three soil types (sandy, silty and clay), Deasy et al. (2009) showed that compared to losses from cropped areas without tramlines, losses of sediment and $\mathrm{P}$ were between 2 and 230 and 2 and 293 times greater from tramline areas, respectively. The increase in losses due to tramlines was lower for the clay soils and greater for the silty soils, largely due to the cohesiveness of the clay soil. It is important to note, however, that tramline areas normally only account for about 5\% of the field area. Accelerated rates of soil erosion within agricultural landscapes are causing major modifications to terrestrial carbon, nitrogen and P cycling (Quinton et al. 2010). Measures that can help maintain or increase SOC include: adoption of reduced tillage; straw incorporation; use of 
organic manures; use of cover crops; and adoption of mixed rotations (Hackett 2010). Increases in SOC resulting from management changes are slow and reversible (Hackett 2010).

Other contributors to erosion under modern intensive arable production systems are:

- ditch removal and field enlargement;

- use of high-powered modern traction systems, which can plough up and down slopes rather than contour ploughing (Quinton and Catt 2004);

- use of heavy rollers after sowing (Boardman 1990); and

- loose, fluffy and very fine seed bed conditions (Speirs and Frost 1987; Catt et al. 1998).

The removal of hedgerows, ditches and open drains is now prohibited as part of EU cross compliance. Key tillage operations/practices that may impact on soil and water quality and possible mitigation options for Ireland are outlined in Table 2.

\section{IMPACT OF TILLAGE FARMING}

Soil loss on arable agricultural land is typically an order of magnitude higher than under undisturbed native vegetation (Van Oost et al. 2009), and two orders of magnitude higher than rates of soil formation (Montgomery 2007). There is much evidence to show that soil erosion due to rainfall and overland flow is exacerbated by tillage operations. Of similar importance, however, is the extent of tillage erosion resulting directly from tillage operations. This generally results in a movement of soil from convex- to concaveshaped landscapes and leads to a nutrient-rich soil in the latter. While water erosion is strongly controlled by soil characteristics such as soil stone level, texture and crusting potential (Van Oost et al. 2009), experimental studies have shown that tillage speed, depth, direction and implement characteristics are the primary controls on tillage erosion (Van Oost et al. 2006). It is of major importance that eroded nutrients and sediment are retained in-field so as not to impact on surface water quality.

Given that rates of soil redistribution in the medium term are influenced by tillage displacement as well as water erosion, it is necessary to separate these two components of soil redistribution in order to obtain a reliable assessment of water erosion rates (Blake et al. 1999). By using a tillage erosion diffusion-type model based on the one proposed by Lobb et al. (1999) and landuse databases, Van Oost et al. (2009) estimated that the mean gross tillage erosion rate for the part of Europe covered by the CORINE land use database was $3.3 \mathrm{t} \mathrm{ha}^{-1}$ year $^{-1}$. For the same land area, they estimated that the average water erosion rate was $3.9 \mathrm{t} \mathrm{ha}^{-1}$ year $^{-1}$ by using water erosion estimates for arable land, orchards and vineyards compiled in a study by Cerdan et al. (2006) of datasets from 81 experimental sites across nineteen European countries. The model also included large-scale land use (CORINE), soil (Soil Geographical Database of Europe), topography (Shuttle Radar Topography Mission; Ciat 2004) and soil erodibility datasets for Europe. For the cropland area of Ireland, the same models estimated the average tillage and water erosion rates to be $2.9 \mathrm{t} \mathrm{ha}^{-1}$ year $^{-1}$ and $4.4 \mathrm{tha}^{-1}$ year $^{-1}$, respectively. These erosion rates are higher than average rates of soil formation (consisting of mineral weathering, soil biomass growth and dust deposition), which range from $0.3 \mathrm{t} \mathrm{ha}^{-1}$ year $^{-1}$ to $1.4 \mathrm{t} \mathrm{ha}^{-1}$ year $^{-1}$, with the lower limit being indicative of European conditions (Creamer et al. 2010). Research on tillage soils in Ireland is needed to validate the estimates of erosion rates given by the model used by Van Oost et al. (2009).

The potential TP losses associated with these estimates of erosion could have serious implications for water quality in Ireland if the eroded sediment reaches surface water bodies, given that the typical range for TP content of non-polluted agricultural soils in Ireland is estimated at between 0.02 and $0.20 \%$ (McGrath et al. 2001) with the median TP content of Irish soils $(0-10 \mathrm{~cm})$ being $0.11 \%$ (Fay et al. 2007). Applying this range of TP in Irish agricultural soils to the estimates of water erosion reported by Van Oost et al. (2009) for Ireland gives a loss of $0.88 \mathrm{~kg} \mathrm{P} \mathrm{ha}^{-1}$ year $^{-1}$ to $8.8 \mathrm{~kg} \mathrm{P} \mathrm{ha}^{-1}$ year $^{-1}$ from arable land. This is a conservative estimate of $\mathrm{P}$ loss from arable fields due to erosion, given that $\mathrm{P}$ has low solubility and is primarily bound to finer soil fractions like clay, which runoff preferentially transports (Quinton et al. 2001). In a study of TP export coefficients from different CORINE land-cover classes in 50 experimental sub-catchments of the rivers Colebrooke and Upper Bann in Northern Ireland, Smith et al. (2005) determined the TP export coefficient from non-irrigated arable land to surface waters to be $4.88 \pm 1.12 \mathrm{~kg} \mathrm{P} \mathrm{ha}^{-1}$ year $^{-1}$ with $95 \%$ confidence limits. This export coefficient was almost twice as high as that measured during the study for any other CORINE land-cover class and almost five times as high as the export coefficient for pasture.

With the exception of tillage erosion occurring adjacent to waterways, soil transported 
Biology AND ENVIRONMENT

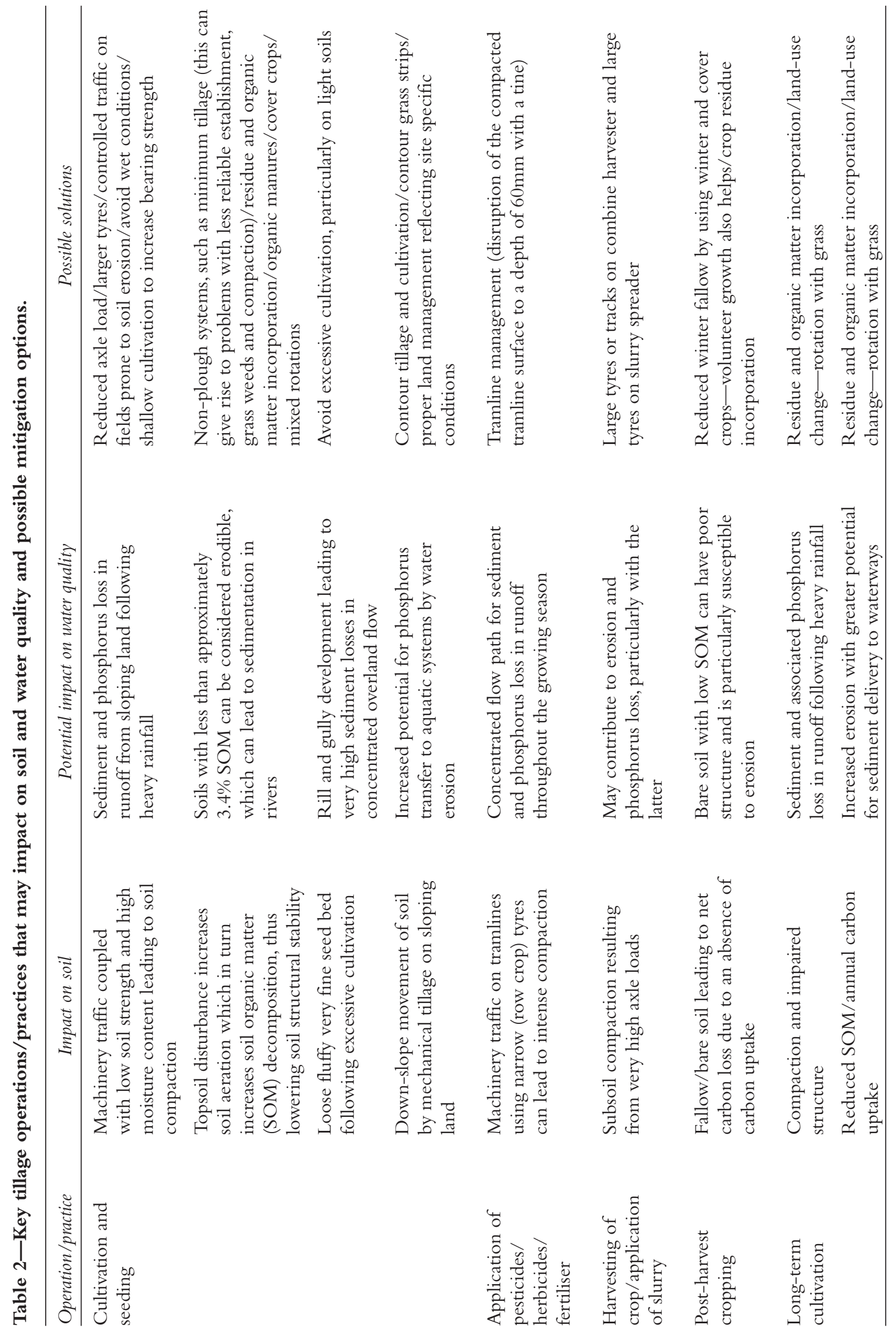


in the field by mechanical tillage operations is unlikely to reach surface waters without transportation by water erosion. Though tillage erosion does not have the same direct detrimental effect on surface water quality as water erosion, it can increase the risk of nutrient delivery to waterways by progressive accumulation of nutrient-rich sediment in low-lying areas of fields that may be exposed to concentrated overland flow and leaching. It must therefore be accounted for in any assessment of soil erosion. If field- and catchment-scale research is to identify sediment sources and test mitigation options within arable areas, it must be designed to explicitly attribute losses to tillage or water erosion processes. This will require the assessment of each type of erosion in isolation and while interacting with one another. This is essential if we are to understand the role played by tillage erosion in delivering sediment to surface waters.

Rainfall variability in Ireland often results in tillage field operations being carried out in less favourable conditions (soils at or near field capacity) with increased risk of soil compaction from field machinery traffic. The trend towards larger machines with increased axle loads further increases the risk of soil compaction. Compacted soils with poor structure are more prone to surface capping and poor infiltration of water due to reduced porosity and consequent reduction in hydraulic conductivity, leading to earlier saturation and thus increased surface runoff and erosion in sloping areas. Soil compaction can occur as surface compaction, i.e. within the tilled layer or as subsoil compaction that occurs beneath the plough layer. Surface compaction is normally dealt with in the next tillage operation, while subsoil compaction is much more persistent and difficult to remove. While subsoiling has been the subject of much research and can reduce bulk density and compacted layers, it is generally considered better to avoid subsoil compaction than to rely on alleviating the compacted soil layer afterwards (Allakukku et al. 2003; Spoor et al. 2003). Prevention of subsoil compaction is essential for economically and environmentally sustainable agriculture (Arvidsson et al. 2000). Compaction can be reduced by:

- the use of low ground pressure wheel equipment on machinery (Chamen et al. 2003);

- working in good soil moisture conditions and minimising the weight of machinery (Van den Akker et al. 2003);

- minimising the number of passes made by machinery (Marsili et al. 1996); and

- controlled traffic systems (Chamen et al. 2003).
MEASURING AND QUANTIFYING SOIL EROSION ON ARABLE LAND

There is a need for information on both gross and net erosion rates from agricultural land so that the sediment delivery ratio (SDR), or proportion of the sediment mobilised by soil erosion that is transported towards local watercourses, rather than being deposited close to the original source, can be determined (Blake et al. 1999). If the level of erosion of Irish tillage soils is to be accurately determined, work must be undertaken that quantifies the rates of soil movement to surface water at the catchment scale.

Traditional monitoring techniques used to establish soil erosion rates have the inherent flaw of failing to determine the fate of eroded sediment and, therefore, give no indication of the impact of measured erosion rates on surface water quality. Blake et al. (1999) note that it is particularly difficult to assemble information on the spatial distribution of erosion and deposition rates within the landscape and on the associated SDRs using traditional monitoring techniques. Much of the information available on erosion rates has been collected from flume and erosion plot studies; however, these only provide information on the net rate of soil loss from the bounded area, as represented by the flux of sediment across its lower boundary. As such, plot studies typically overestimate erosion rates by failing to encompass major catchment sediment stores (Collins and Walling 2007). These stores get larger as the catchment area increases because the fraction of less steep slopes, such as valley bottoms where sediment deposition occurs, also increase (Verstraeten and Poesen 2001). It is for these reasons that the representativeness of plot results, in terms of the wider landscape, is often questioned. As the scale at which erosion is being studied increases from flume-to-plot and up to field- and catchmentscale, the parameters influencing this erosion change and, therefore, so must methods used to measure erosion. The use of sediment fingerprinting and composite fingerprints to determine the provenance of eroded sediment is one preferable method for use at larger scales, which will be discussed later.

\section{MEASURING AND QUANTIFYING PHOSPHORUS TRANSFER FROM ARABLE SOIL TO WATER}

Soil cultivation is a major factor contributing to an increased risk of particulate phosphorus 
(PP) transfer to water, but when reduced cultivation such as non-plough tillage is practised to decrease losses of PP there can be a build-up of $\mathrm{P}$ near the soil surface that increases the risk of DRP loss in surface runoff. P loss can also occur through drainage, however, with the most significant instances of downward movement of $\mathrm{P}$ through the soil profile being associated with excessive application of $\mathrm{P}$ in manure and fertiliser (Sims et al. 1998; Murphy 2007), in particular, on soils with low P-retention properties and/or significant preferential flow pathways, for example cracking clay soils (Hart et al. 2004).

\section{PHOSPHORUS MOBILISATION}

Mobilisation is the first key step in the separation of $\mathrm{P}$ molecules from their source and includes chemical, biological and physical processes. These processes group into either solubilisation or detachment mechanisms, defined by the physical size of the $\mathrm{P}$ compounds that are mobilised (Haygarth et al. 2005). The detachment and transfer of non-dissolved $\mathrm{P}$ in association with soil particles is more pronounced where farming practices generate erosion (Chamber et al. 2000) and provides a physical mechanism for mobilising $\mathrm{P}$ from soil into surface waters (Sharpley and Smith 1990; Toy et al. 2002). The size threshold most commonly used to operationally define detachment is $>0.45 \mu \mathrm{m}$ and has been used for the threshold between DP and PP (Haygarth and Jarvis 1997). Haygarth and Jarvis (1999) have argued for the inclusion of a third mode by which $\mathrm{P}$ can be mobilised for transport to water: the incidental transfer of DP and PP occurring when fertiliser or manure applications, which are not incorporated into the soil, are coincident with onset of rainfall. They conclude that, even though incidental transfer will include mobilisation and detachment, it should be kept separate from these mechanisms due to the unique circumstances leading up to its occurrence and control. The relative proportions of PP and DP in surface runoff are dependent on the complex interaction between climate, topography, soil type, soil $\mathrm{P}$ content, type of farming system and farm management (Withers 1999).

PP includes all primary and secondary mineral $\mathrm{P}$ forms, plus organic $\mathrm{P}, \mathrm{P}$ sorbed by minerals and organic particles eroded during runoff. It constitutes the major proportion of $\mathrm{P}$ transported from cultivated land (75-90\%; Sharpley et al. 1995). Fang et al. (2002) reported that PP contributed from 59 to $98 \%$ of total runoff $\mathrm{P}$ for un-vegetated packed flumes. Unlike most DRP, which is readily available for plant uptake, PP acts as a long-term source of $\mathrm{P}$ for submerged aquatic vegetation and algal growth (Sharpley 1993; Søndergaard et al. 2001), particularly in lakes where inflowing rivers deposit nutrient-enriched sediment on the lake floor. P release at the sediment-water interface may occur in the following conditions:

- during periods of anoxia or hypoxia (Theis and McCabe 1978; Steinman and Ogdahl 2008);

- by wind-induced resuspension and bioturbation (Steinman and Oghahl 2008); or

- an increase in $\mathrm{pH}$ of the interstitial water (Sharpley and Rekolainen 1997; Daly 1999).

The expensive nature of field experiments and inherent variability in natural rainfall has made rainfall simulators and laboratory microcosms a widely used tool in $\mathrm{P}$ transport research (Hart et al. 2004). Due to the complexity of soil erosion by water, field experimentation can be complimented by work in controlled laboratory experiments. While there are still some reservations regarding the use of simulated rainfall in place of natural rainfall (Potter et al. 2006), there is widespread support for the use of rainfall simulation experiments to obtain some estimate of the magnitude of potential losses from different land management systems, soil types, and landscapes (Pote et al. 1999; Bundy et al. 2001; Sharpley et al. 2001b; Schroeder et al. 2004; Tarkalson and Mikkelsen 2004; Little et al. 2005). Numerous studies outside Ireland have utilised rainfall simulation to evaluate nutrient losses in runoff from tillage systems (Andraski et al. 1985; Zhao et al. 2001; Daverede et al. 2003; Franklin et al. 2007). Studies have also been conducted using laboratory rainfall simulation on flumes packed with tillage soil to predict the runoff of SS and PP using simple soil tests (Udeigwe and Wang 2007). They have also been used to examine variability in the mobilisation and transport of nutrients and sediment by overland flow across a range of soils (Miller and Quinton 2009). In addition, flume studies using concentrated overland flow as opposed to simulated rainfall have been used by Knappen et al. (2008) to show that the effect of conservation tillage on soil detachment rates is a result of soil property modifications affecting soil erodibility, rather than a result of the surface residue decreasing flow erosivity. Laboratory-scale work such as this is essential in understanding erosion processes and in selecting suitable erosion-prevention measures for further testing at larger scales. 


\section{PHOSPHORUS SOURCE AREAS}

The loss of $\mathrm{P}$ tends to be highly sporadic in nature and is often restricted to small geographic areas (Edwards and Withers 2008). In many regions, small portions of saturated land, known as variable source areas (VSAs), generate the majority of overland flow (Doody et al. 2006), the occurrence of which is largely independent of rainfall intensity (Walter et al. 2000). This type of runoff is known as saturation excess runoff. A VSA can contract and expand both seasonally and during storms as a function of precipitation, topography, soil type, soil moisture status, and water table level (Hart et al. 2004). The occurrence of high STP within a VSA results in a critical source area (CSA) of P (Gburek and Sharpley 1998).

A large proportion (up to $90 \%$ ) of $\mathrm{P}$ exported from catchments on an annual basis is generated from a relatively small portion of the catchment and during only one or two storm events (Sharpley and Rekolainen 1997). Tunney et al. (2000) showed that $40 \%$ of the total amount of DRP lost in runoff for 1997 from four grassland fields ranging in size from 0.5 ha to 14.5 ha was lost when about $150 \mathrm{~mm}$ of rain fell in a four-day period. In contrast, a study of nutrient and sediment loss to water from agricultural grassland catchments of the Dripsey River, County Cork in 2002, found that more than $80 \%$ of TP loss occurred in the five months of October to February, with a large proportion coming from about ten storm events where high $\mathrm{P}$ concentrations occurred simultaneously with high stream flows (Lewis 2003). This evidence suggests that, while extreme rainfall events with large return periods like that reported by Tunney et al. (2000) can be responsible for a large proportion of DRP lost over an atypical year, more normally we would expect $\mathrm{P}$ loss to be spread across a number of large storms throughout the year. In addition, research at plot-scale on arable land in the UK by Quinton et al. (2001) showed that more frequently occurring smaller events accounted for a greater proportion of the $\mathrm{P}$ lost over a six-year period than infrequent large events. It is important to note that losses in the study by Quinton et al. (2001) were measured at the end of an erosion plot and that even though a smaller proportion of $\mathrm{P}$ was lost in larger events, these events have greater transport potential and are more likely to deliver eroded sediment and $\mathrm{P}$ to surface waters.

The identification of CSAs, where the potential for pollution is higher, has significant implications for RBMPs, because the blanket application of a specific mitigation measure across an entire catchment will not be as cost-effective as its deployment solely in those areas where it is most appropriate.
Pionke et al. (1997) suggested that effective mitigation of $\mathrm{P}$ losses from agriculture must focus on defining, targeting and remediating CSAs of P loss. Hughes et al. (2005) used field and catchment-scale ranking schemes to identify CSAs for P loss in Ireland. Outside the VSAs, runoff may be triggered when the infiltration capacity of the surface soil is exceeded, usually following high-intensity storm events. Both saturation and infiltration-excess runoff occur in Ireland and, though the latter is less common, research has shown that it does occur (Schulte et al. 2006a). At field-scale, runoff collection is complicated in areas with a perched water table. The divisions between saturated and infiltration runoff become difficult as a VSA is generated.

\section{MODELLING SOIL EROSION AND SEDIMENT AND P DELIVERY TO SURFACE WATERS AT THE CATCHMENT SCALE}

Information on soil erosion and $\mathrm{P}$ loss across different land uses (e.g. tillage and grassland) and its effect on water quality at catchment scale will help Ireland meet the requirements of the WFD. Detailed analysis of catchment characteristics, assessment of risk to surface and ground waters, further analysis of existing information and collection of new data are all needed to support the implementation of the WFD (Irvine et al. 2005). Given that there is still much to understand about the complex relationship between the catchment and the movement of sediment and $\mathrm{P}$, and the response of the aquatic ecosystem to anthropogenic impacts, modelling that can elucidate key variables and predict responses is a valuable tool (Irvine et al. 2005).

Many different kinds of models are available for use in simulating soil erosion and sediment and $\mathrm{P}$ delivery to waterways at the catchment scale. In general, these models fall into three main categories: empirical; conceptual; and physical- or process-based. The difference between the model categories is not always clear, however, and making the distinction can be somewhat subjective (Merritt et al. 2003). For example, it has been argued by Lowe (2006) that the Hydrological Simulation Program - Fortran (HSPF, Bicknell et al. 1997), which has been classed as a conceptual model by many studies is, in fact, a physically-based model. Previous work by Merritt et al. (2003) provides a comprehensive review of erosion and sediment transport models. For the purposes of this review, the focus will 
be on catchment-scale models that have been used in Ireland to estimate soil erosion, and $\mathrm{P}$ and sediment delivery to waterways. These are empirical models [Revised Universal Soil Loss Equation (RUSLE) and Sediment Distribution Delivery (SEDD)] and physically based models [Hydrological Simulation Program-Fortran (HSPF) (Bicknell et al. 1997), Soil Water Assessment Tool (SWAT) (Arnold et al. 1998), Système Hydrologique Européen TRANsport (SHETRAN) (Ewen et al. 2000)] and modified version of TOPMODEL (Scanlon et al. 2005).

Where possible, the losses estimated using these models are compared with losses from the same models applied in other countries and with measured losses from Irish and international catchments (Tables 3 and 4). Caution is required when comparing results from these tables, given the effect of catchment size on suspended sediment yield.

\section{EMPIRICAL MODELS}

These models are generally considered to be the simplest of the three model types. They are frequently used in preference to more complex models as they can be implemented in situations with limited data and parameter inputs. They are particularly useful as a first step in identifying sources of sediment and nutrient generation (Merritt et al. 2003). These models are derived from the analysis of field observations and endeavour to characterise response from these data.

The Universal Soil Loss Equation (USLE; Wischmeier and Smith 1978) is a program used widely in America and worldwide that estimates the long-term water erosion from interill and rill areas. It is represented by the equation: $A=R K L C S P$, where $A$ is the estimated soil loss per unit area, $R$ is the rainfall erosivity factor, $K$ is the soil erodibility factor, $L$ is the slope-length factor, $S$ is the slopesteepness factor, $C$ is the cover and management factor and $P$ is the support practices factor. The USLE was revised (RUSLE; Renard et al. 1991) and revisited (Renard et al. 1994) to take into account additional information that had become available since its development. Although developed for application to small hill slopes, the USLE and its derivatives have been incorporated into many catchment-scale erosion and sediment transport modelling applications (Merritt et al. 2003).

The SEDD model is based on the USLE model. It discretises a catchment into morphological units (areas of defined aspect, length and steepness) and determines a SDR for each unit (Fernandez et al. 2003). The SDR is the ratio of sediment reaching a continuous stream system to the total amount of sediment eroded by sheet and channel erosion. The magnitude of the SDR for a particular catchment will be influenced by a wide range of geomorphological, hydrological, environmental and catchment factors (Fu et al. 2006).

The combined use of Geographical Information Systems (GIS), RUSLE and SEDD has been shown to be an effective method for estimating water erosion and sediment yield by Fernandez et al. (2003) and Fu et al. (2006). It is also effective for estimating the impacts of no-till practice on soil erosion and sediment yield (Fu et al. 2006). A case study in Ireland by He (2010) to estimate soil erosion and sediment yield using GIS, RUSLE and SEDD predicted that the average SS delivered from arable land to waterways was $0.22 \mathrm{t} \mathrm{ha}^{-1}$ year $^{-1}$. This finding should be treated with caution because the catchmentspecific parameter $\beta$ was only estimated for the Dripsey catchment (using an inverse modelling approach employing observed SDR values from fields) and sensitivity analysis of $\beta$ by increments of 1.0 to a maximum of 20.0 was carried out to infer possible values of $\beta$ for the Bandon, Dromcummer, Duarrigle and Mallow catchments. Fu et al. (2006) tested $\beta$ between 0.5 and 2.0 with an increment of 0.1 and found that the SDR was very sensitive to the values of $\beta$, varying from $0.6(\beta=0.5)$ to $0.27(\beta=2.0)$.

\section{PHYSICALLY-BASED MODELS}

Physically based models are those in which the model equations are based on physical laws and relationships. They are more complex than empirical models and require more measurement and calibration of model parameters. Complex physical models applied with the necessary expertise or user support can be far superior where there is a need to address spatial and temporal complexities (Irvine et al. 2005). According to the Drivers, Pressures, State, Impact and Response (DPSIR) conceptual framework (Irvine et al. 2005) that guides the selection of modelling techniques in Ireland, it is likely that the most useful models will be of the physically-based or mechanistic type (Nasr et al. 2007).

Nasr et al. (2007) tested three widely-used physically-based models (SWAT, HSPF and SHETRAN, coupled with the grid-orientated P component (GOPC; Nasr et al. 2005) of diffuse P pollution, in three Irish grassland catchments in order to explore their suitability in Irish conditions for future use in implementing the WFD. These models range from semi-empirical (SWAT) to fully physically-based (SHETRAN/GOPC) 
Phosphorus AND SEDIMENT RELEASE FROM SOILS

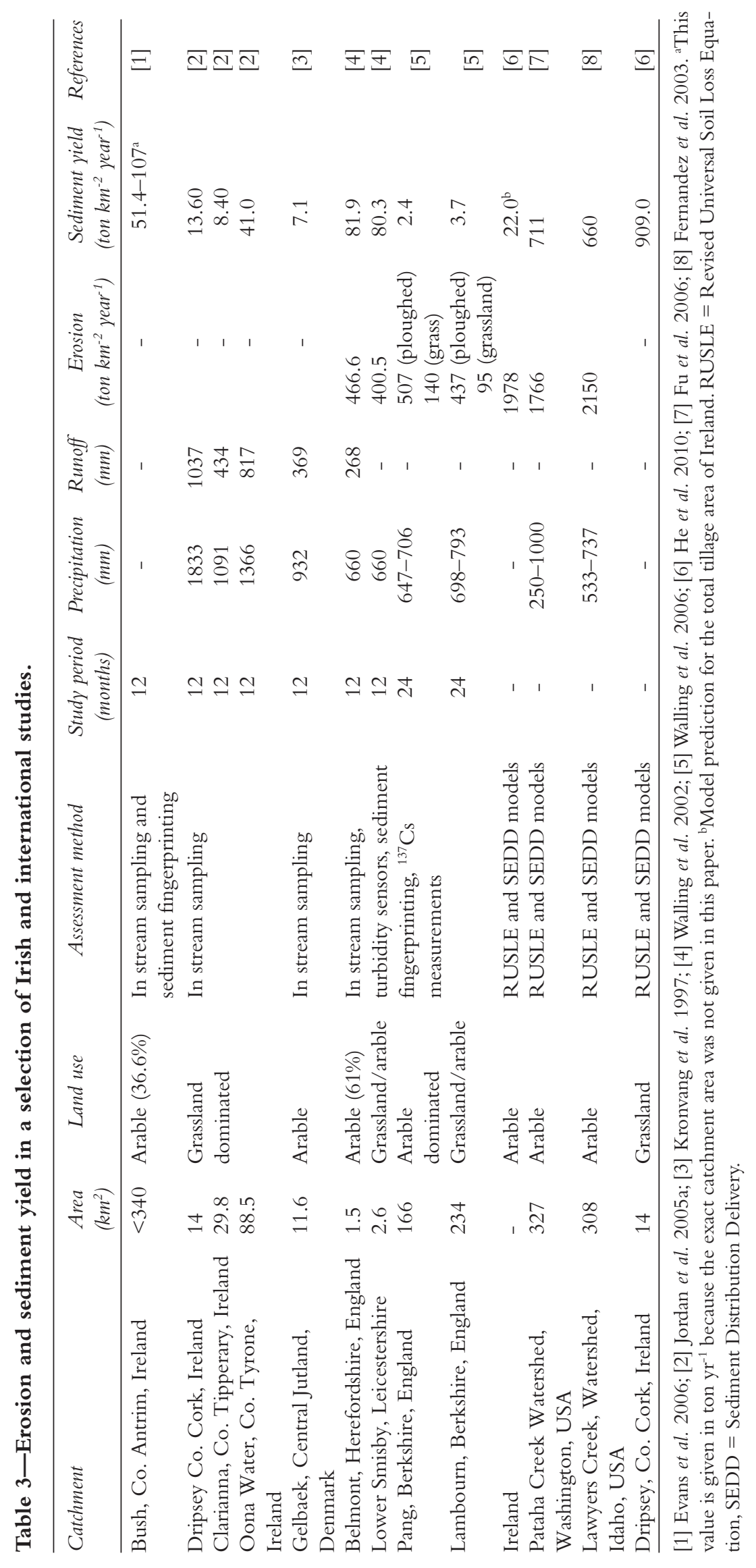


Biology AND ENVIRONMENT

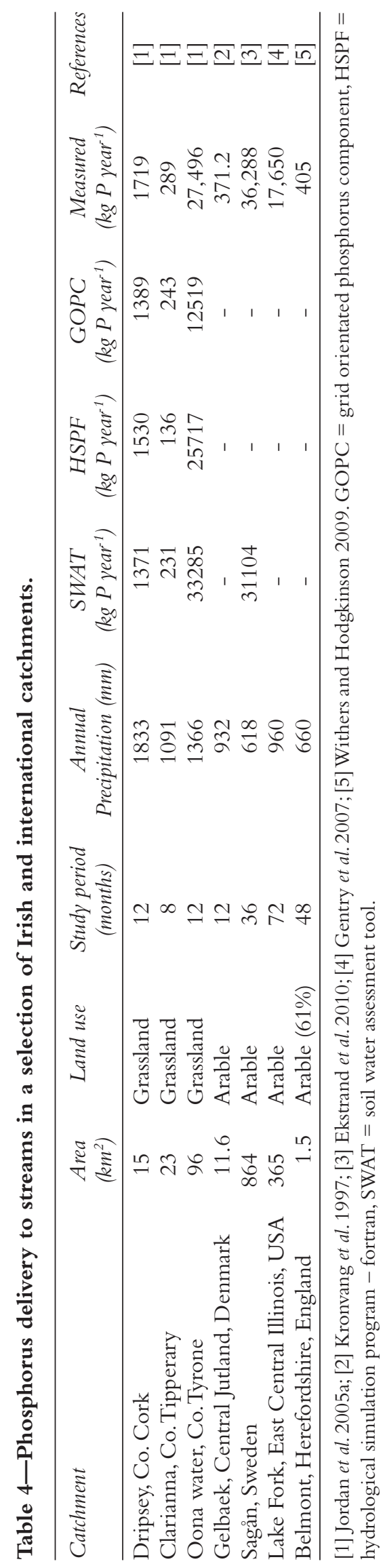


in how they represent the relevant hydrological, chemical and biochemical processes transforming the $\mathrm{P}$ compounds both in the soil and during their transport by water (Nasr et al. 2007). The catchments were selected based on data availability and different climates, land use and soil type. SWAT is a continuous model working at the basin-scale to look at the long-term impacts of management and timing of agricultural practices within a year on water, sediment, and agriculture chemical yields in large un-gauged basins (Arnold et al. 1998). HSPF is a lumped-parameter model that simulates hydrology and water quality processes on a continuous basis in natural and man-made water systems (Im et al. 2003). SHETRAN/ GOPC is a fully physically-based model that relies on relationships derived from physical and chemical laws. The three models also differ in their representation of the spatial variation within the catchment and the time steps at which they can simulate. In order of ability, to match the measured discharge hydrographs from each catchment in this study, the models performed (from best to worst) as follows: HSPF, SWAT, SHETRAN. The best simulation for daily TP loads in the study catchments was by SWAT. In the short term, Nasr et al. (2005) recommended using SWAT for TP load estimation. The SWAT model recently showed good potential for predicting TP losses from arable land in a Swedish study by Ekstrand et al. (2010) (Table 4).

TOPMODEL is a process based semidistributed catchment model (Irvine et al. 2005) in which the major factors affecting runoff generation are the catchment topography and the soil transmissivity, which diminishes with depth (Parsons et al. 2001). In this model, overland flow generation follows the VSA concept while groundwater discharge is from a permanent water table. TOPMODEL is not intended to be a traditional modelling package, but a collection of concepts to help in understanding and predicting the hydrological behaviour of basins (Parsons et al. 2001). It was used for this purpose by Scanlon et al. (2005) when a modified version of TOPMODEL was developed and applied to a 14.26-ha grassland catchment in Ireland in order to infer the significant pathways of soil-to-stream $\mathrm{P}$ transport. In this study, a physically-based hydrological model generated pathway-specific information for three components of discharge: overland flow, shallow subsurface flow and groundwater discharge. An independent comparison of the hydrological model output and stream water $\mathrm{P}$ measurements allowed the authors to infer the relative contributions from individual pathways to the overall $\mathrm{P}$ transport. They found that the fraction of modelled stream discharge deriving from overland flow and shallow subsurface flow was a reliable descriptor of the observed TP concentrations. Shallow subsurface flow was inferred to be the dominant $\mathrm{P}$ transport mechanism, primarily due to much greater volumetric contributions to stream discharge deriving from it than from overland flow. These model results challenge the commonly-held assumption that the majority of $\mathrm{P}$ transport occurs via surface runoff and could have important implications for the design and implementation of remedial measures (Scanlon et al. 2005).

\section{MITIGATION MEASURES TO PREVENT EROSION ON TILLAGE SOILS}

Various land management practices have been shown to minimise erosion risk on susceptible soils: low erosion risk crops and cover crops, tillage timing and intensity, and the use of buffer strips (Creamer et al. 2010). For example, intensively cultivated soils amended with spent mushroom compost, a by-product of the mushroom-growing industry in Ireland, exhibited improved structural stability as measured by an aggregate stability test (Curtin et al. 2007). The UK Department for Environment, Food and Rural Affairs (Defra) highlights potatoes, winter cereals, sugar beet, maize and grazed fodder crops as having the highest erosion risk based on crop cover (Defra 2005). To minimise erosion risk on susceptible soils, low-risk crops like oilseed rape, which establish a crop cover earlier, should be sown (Chambers and Garwood 2000). Furthermore, winter barley may be more beneficial than spring barley as it provides winter cover. Wet weather trafficking may, however, offset benefits.

Minimum (or minimal) tillage, which involves shallow cultivation to a maximum depth of $10 \mathrm{~cm}$ using a tine cultivator, helps conserve SOM, promotes aggregate stability and thus reduces erosion (Quinton and Catt 2004). In Ireland, minimum tillage normally involves:

- shallow cultivation using a tine cultivator or disc harrow to a depth of $75-100 \mathrm{~mm}$ immediately followed by rolling;

- spraying with herbicide a few days prior to sowing, following a stale seedbed period of a number of weeks (where possible) to eliminate volunteers and established weeds; and

- sowing with a cultivator drill to a target depth of $40 \mathrm{~mm}$ (Forristal et al. 2009).

To date, the effectiveness of minimum tillage at reducing erosion has not been investigated in Ireland. Research in the UK by Deasy et al. 
(2009) found that for five site years trialled, losses of SS and TP decreased by an average of $151 \mathrm{~kg}$ $\mathrm{SS} \mathrm{ha} \mathrm{h}^{-1}$ and $0.3 \mathrm{~kg} \mathrm{TP} \mathrm{ha} \mathrm{h}^{-1}$, respectively, under minimum tillage compared to traditional plough cultivation. Contour grass strips have received some research attention and have been shown to reduce sediment losses (Stevens et al. 2009) by reducing slope length and by acting as a barrier to slow down overland flow. Deasy et al. (2010) found that although minimum tillage, crop residue incorporation, contour cultivation and beetle banks (raised vegetative barriers placed on the contour) all have potential to be cost-effective mitigation options for SS and TP losses, tramline management (disruption of the compacted tramline surface to a depth of $60 \mathrm{~mm}$ with a tine) is one of the most promising treatments for mitigating diffuse pollution losses. (It was able to reduce sediment and TP losses by $72-99 \%$ in four out of five site years trialled. As a management practice to reduce P loss from tillage soils in Ireland, Carton et al. (2002) advised that attention be paid to tramline compaction and that, if soils become severely compacted, corrective action such as subsoiling should be taken where appropriate.

The Nitrates Directive (91/676/EEC), as implemented in the Republic of Ireland, sets out crop cover requirements where arable land is ploughed between 1 July and 30 November. The regulations require that the owner/occupier take appropriate measures to provide for the emergence of green cover from a sown crop within six weeks of ploughing. In the UK, as part of the crosscompliance regime (Defra 2006), farmers are further required to carry out a field-erosion risk assessment as a means of reducing risk to acceptable levels. The validity of this approach to erosion risk identification was verified by Boardman et al. (2009). Conservation tillage in autumn may reduce losses of soil and $\mathrm{PP}$ by improving soil structure. In Norway, ploughing and shallow cultivation of sloping fields in spring instead of ploughing in autumn have been shown to reduce particle transport by up to $89 \%$ on highly erodible soils (Ulén et al. 2010). Rational land-use policies, such as the promotion of 'set-aside' on erodible soils, the use of grass strips on erodible arable slopes and buffer strips in riparian zones, were identified as mitigation options for reducing soil erosion by Fullen et al. (2003).

There are some preventative measures in place to prevent land degradation processes from arable agriculture (Table 2). In the Republic of Ireland, farmers protect vulnerable tillage soils by complying with 'good agricultural and environmental conditions' guidelines as a condition for receipt of the area-based single farm payment under the
EU cross-compliance regime (Department of Agriculture and Food 2005). Land that has been in continuous tillage for six years or more must be tested for organic matter content as a requirement for the single payment scheme. Soils having less than 3.4\% SOM may require remedial action, depending on soil type. As the process of building up SOM is very slow, the remedial action to be taken is set out over a ten-year period. The remedial action will continue until such time as the organic matter levels are shown to have recovered to greater than $3.4 \%$ or a level deemed acceptable for that soil type. Hackett et al. (2010) provide information on how various management practices affect SOC dynamics in arable soils. Land application of fertiliser and manures is now subject to 'closed periods' that coincide with the most frequent average occurrence of transport vectors. Farmers are also prohibited from applying fertilisers in close proximity to a watercourse. 'Buffer strips' of $2 \mathrm{~m}$ and $5 \mathrm{~m}$ for mineral fertiliser and organic fertilisers, respectively, must be observed. The effectiveness of these aspects of the regulations is currently being monitored in the Agricultural Catchments Program (Schulte et al. 2010b).

Soil data currently available in Ireland exist in variable forms and are not fully mapped at the target European scale (1:250,000). Spatial soil mapping, combined with conservative groundtruthing, is currently underway in the form of the Irish Soil Information System. This aims to complete the soil map of Ireland at a 1:250,000 scale (EPA 2009). In a review of strategies to improve soil conservation in Europe, Fullen et al. (2006) identified several best management practices including: the initiation of national soil conservation services; and full mapping, monitoring and costing of erosion risk by national soil survey organisations. If the SFD is eventually ratified, Ireland will be required to identify areas where erosion has occurred in the past or is likely to occur in the future. At that time, the soil information provided by the Irish Soil Information System will be essential in identifying these areas.

FUTURE RESEARCH DIRECTION IN THE QUANTIFICATION OF NUTRIENT AND SEDIMENT LOSS FROM IRISH TILLAGE SOILS

\section{SEDIMENT PROVENANCE}

Traditional techniques, aimed at identifying the source and the pathway of the sediment have included methods such as risk assessments, 
field observation and mapping (Lao and Coote 1993), landowner questionnaires (Krause et al. 2008), remote sensing (Vrieling 2006), use of erosion pins (Lawler et al. 1997), and terrestrial photogrammetry (Barker et al. 1997).

Given the time and cost involved in establishing and operating plot experiments, and the fact that data available from them are limited, attention has been directed towards the use of environmental radionuclides for documenting erosion rates (Sepulveda et al. 2008). By comparing the fallout radionuclide Caesium-137 $\left({ }^{137} \mathrm{Cs}\right)$ inventory at a particular sampling point with the reference inventory (the total ${ }^{137} \mathrm{Cs}$ activity per unit surface area for a level, stable undisturbed site), the rates of soil erosion and deposition at that point can be estimated. Measurements of ${ }^{137} \mathrm{Cs}$ and the fallout radionuclide unsupported ${ }^{210} \mathrm{~Pb}$ afford a means of obtaining retrospective, medium-term (i.e. c. 45 years for ${ }^{137} \mathrm{Cs}$ and up to 100 years for unsupported ${ }^{210} \mathrm{~Pb}$ ) estimates of both the magnitude and spatial distribution of soil redistribution rates generated by sheet and rill erosion, by means of a single site visit (Blake et al. 1999). Due to its long retention time on soil particles once absorbed, ${ }^{137} \mathrm{Cs}\left(\mathrm{t}_{1 / 2}=30.1\right.$ years $)$ has the disadvantage of not being suitable for the investigation of erosion resulting from individual events occurring over short periods, and is unable to distinguish between tillage and water erosion. It can, however, be used to estimate changes in soil erosion rates associated with changes in soil management practices on cultivated land (Schuller et al. 2004). In contrast to ${ }^{137} \mathrm{Cs},{ }^{7} \mathrm{Be}$ is short-lived with a half-life of only 53 days and. As such, is ideal for estimating short-term rates and patterns of soil redistribution relating to individual events (tillage or water erosion) or short periods of time.

The radionuclides ${ }^{137} \mathrm{Cs},{ }^{7} \mathrm{Be}$, and ${ }^{210} \mathrm{~Pb}$ have different distributions in the soil profile, so their measurement in eroded sediment, referred to as 'sediment fingerprinting', will determine at what depth in the profile the soil was eroded from. Hence, they will give the depth and areal extent of sheet and rill erosion, which can be quantified as was done in a study by Whiting et al. (2001). When estimating sediment erosion rates, sediment fingerprinting has the added advantage over plot studies of identifying both the source and fate of eroded sediment, which has significant implications for the development of best management practices in addressing soil erosion and sediment delivery to waterways. Sediment fingerprinting correlating land use with river sediment appears to offer a valuable alternative to direct monitoring for elucidating the provenance of SS and the relative importance of spatial zones or sub-catchments comprising larger $\left(>500 \mathrm{~km}^{2}\right)$ drainage basins (Collins et al. 1998).

In a study of one of Northern Ireland's prime salmon rivers (The River Bush) aimed at quantifying fine sediment loads and tracing in-stream fine sediment sources using sediment fingerprinting, Evans et al. (2006) were able to rank the four main agents generating those sources. These agents (in order of greatest importance) were: drainage maintenance work, bank erosion (caused by increasing flow and livestock poaching), ploughed arable land, and forestry clearfell. Ploughed arable land was found to be responsible for $36.6 \%$ of the suspended load and $7.5 \%$ of the bed load measured in Bush River over a one-year period. Evans et al. (2006) commented that the most likely mechanisms for the transfer of topsoil to the river channel occurred after ploughing and prior to planting and harvesting of the crop. The best management practices recommended for the Bush catchment area in order to reduce sediment delivery from arable land by reducing bare ground were:

- critical area planting on land prone to long-term soil erosion;

- planting at appropriate times, as assessed on the basis of storm forecasting; and

- limited vehicle movement across fields prone to soil erosion.

Unfortunately, as Evans et al. (2006) recognised, the one-year period of monitoring in this project was too short to provide a reliable picture of sediment dynamics in the Bush catchment.

\section{P LOSS AND STP IN TILLAGE SOILS}

The relationship between STP in tillage soils and DRP concentration in runoff water needs to be adequately understood and quantified for local soils (Wright et al. 2006). To date, no study has investigated the link between STP and P loss to surface waters from tillage soils in Ireland. Guidelines presently used in Ireland are based on international findings and agronomic nutrient advice. Determination of upper critical limits for P in soil should consider both the STP necessary for economic crop production and that necessary to avoid excessive $\mathrm{P}$ loss due to erosion, surface runoff and leaching. This is essential for the development of $\mathrm{P}$ management guidelines for water quality that will satisfy the requirements of the WFD. Relationships developed between runoff $\mathrm{P}$ and STP have been used in Europe and the USA to establish threshold STP levels above which the potential threat of eutrophication in 
surface waters is unacceptable (Sibbesen and Sharpley 1997; Sims et al. 2002).

In a study to evaluate M3-P as an agrienvironmental soil $\mathrm{P}$ test for the Mid-Atlantic United States of America, Sims et al. (2002) concluded that agronomic soil tests, such as M3-P, can be used to guide environmentally-based $\mathrm{P}$ recommendations. They also pointed out that higher risks are clearly associated with M3-P values that are in excess of the concentrations needed for economically optimum crop yields. As a result of the WFD, there is increasing pressure in Europe and Ireland to develop P-based management practices that will reduce the risk of diffuse losses from agricultural land to surface waters. Modelling of $\mathrm{P}$ for grassland undertaken by Schulte (2006b) showed that it was possible to change the range of the target $\mathrm{P}$ index from 6.0-10.0 $\mathrm{mg} \mathrm{l}^{-1} \mathrm{P}_{\mathrm{m}}$ to 5.1-8.0 $\mathrm{mg} \mathrm{l}^{-1} \mathrm{P}_{\mathrm{m}}$ (Table 1) while still facilitating optimum productivity and herbage quality and minimising the risk of diffuse $\mathrm{P}$ losses to water. Index 3 (5.1-8 $\mathrm{mg}^{-1}$ for grassland) in the new P-index system (Table 1) represents a target index that is both agronomically and environmentally sustainable for all soils (Schulte 2006b) in the Republic of Ireland. The target index for tillage crops $\left(6.0-10.0 \mathrm{mg}^{-1}\right)$ has not changed and it is uncertain whether similar work on tillage soils is necessary, as the risk of diffuse $\mathrm{P}$ loss from them has not been quantified in Ireland.

The adoption of management measures in river basins requires the ability of river basin managers to quantify the importance of different $\mathrm{P}$ pathways, identify and map $\mathrm{P}$ risk areas with a certain spatial resolution, and estimate the effect of various management measures for changes in P losses (Kronvang et al. 2005). Limited resources and time will likely hinder the carrying out of a full P-loss assessment (incorporating site characteristics and nutrient management practices) on all agricultural fields in a catchment. Therefore, in the interim, there is a need to identify a STP level, sometimes referred to as an environmental threshold, above which the improvement of $\mathrm{P}$ management practices should be a high priority.

Using the relationship between STP in five Irish tillage soils and the DRP released in the surface runoff, Regan et al. (2010) developed a runoff dissolved phosphorus risk indicator to identify the STP level above which there may be a potential threat to surface water quality. The results of this study complemented the agronomic guidelines of the Nitrates Directive. This is because they indicate that tillage soils may produce surface runoff $\mathrm{P}$ concentrations in excess of $30 \mu \mathrm{g} \mathrm{l}^{-1}$ (the median phosphate concentration above which significant deterioration is seen in river ecosystems) if their $\mathrm{P}_{\mathrm{m}}$ and M3-P concentrations exceed $9.5 \mathrm{mg}^{-1}$ and $67.2 \mathrm{mg} \mathrm{kg}^{-1}$, respectively.

\section{CATCHMENT-SCALE RESEARCH}

Research that will quantify the $\mathrm{P}$ and sediment losses associated with arable land compared to agricultural grassland in Ireland is underway in the form of the Agricultural Catchments Program. This will provide a scientific evaluation of the effectiveness of the Nitrates Directive National Action Programme measures over time for major farming and environmental stakeholders in Ireland. The program is designed to assess the effectiveness of measures well before improvements are expected to translate into improved water quality in the final aquatic receptors, which in some cases may take up to twenty years (Schulte et al. 2010b). In the first stage, four catchments (two arable and two grassland catchments) from 1500 possible candidates were selected to be included in the study using spatial multi-criteria decision analysis (Fealy et al. 2010). Combined, the four catchments represent the range of intensive grassland and arable agriculture interests in Ireland across a soil and physiographic gradient that defines the potential risk of $\mathrm{P}$ and/or $\mathrm{N}$ transfers (Fealy et al. 2010). A fifth catchment in a karst limestone region in the west of Ireland is also being studied. The arable catchments, having between $30 \%$ and $50 \%$ arable land use in each, are located in County Louth/Cavan on intermediately drained soils and in County Wexford on welldrained soils. This enables the measurement of storm-induced diffuse transfers of $\mathrm{P}$ and losses of $\mathrm{N}$ to groundwater through leaching. The Agricultural Catchments Program will focus on source, pathways and delivery of nutrients to waterways over time. At the outlet of each catchment, the following parameters will be monitored: $\mathrm{TP}$, total dissolved $\mathrm{P}$, total reactive $\mathrm{P}, \mathrm{DR}$, total nitrogen, $\mathrm{NO}_{3}-\mathrm{N}$, turbidity, electrical conductivity, temperature and flow rate. Particular attention will be paid to $\mathrm{P}$ hotspots (fields at soil P index 4) and to linking these to $\mathrm{P}$ loads in streams. This will facilitate the identification of areas that are vulnerable to $\mathrm{P}$ loss and that will require measures to reduce losses. On-site bankside nutrient analysers (Jordan et al. 2007) will enable immediate analysis of nutrients susceptible to transformation if left in sample bottles for long periods of time. The use of turbidity as a surrogate technique for the measurement of SS is also being investigated in the catchments. 


\section{CONCLUSIONS}

The vast majority of research on soil erosion and nutrient loss in Ireland has concentrated on grassland due to its predominance. There is little research dedicated to tillage areas, although internationally, tillage areas have been identified as risk areas. Estimating the environmental risk associated with Irish tillage areas based on international findings is difficult because rainfall, soil type and cultivation practices differ and therefore not all international research findings are relevant within an Irish context. Modelling of water and tillage erosion rates across Europe suggests that soil is being lost at a rate greater than it can be replenished by natural soil formation. This has significant implications for the sustainability of crop production. Furthermore, the occurrence of erosion adjacent to waterways may result in the transfer of $\mathrm{P}$ and sediment. The main conclusions from this review are:

1. As $\mathrm{P}$ transfer to surface water may occur in dissolved form, the relationship between STP in tillage soils and DRP concentration in runoff water needs to be adequately understood and quantified for Irish tillage soils.

2. The ability to identify CSAs of $P$ and the hydrological pathways connecting these areas to surface water bodies is essential if mitigation measures are to be cost effective.

3. Given that a large proportion of $\mathrm{P}$ exported from agricultural catchments on an annual basis is generated from a relatively small portion of the catchment and during a number of large storm events, research to quantify $\mathrm{P}$ and sediment loss from Irish tillage soils should utilise a laboratory-, field- and catchment-scale approach. This approach should be able to identify contributing portions of land within a catchment posing a risk, and also identify and quantify actual releases from the catchment as a whole.

4. Catchment-scale research will help to link CSAs of sediment and P loss with hydrological pathways to surface waters in the catchment. Remedial initiatives set out in the RBMP can then be targeted in these areas and their effectiveness evaluated.

5. Research conducted at laboratory-scale can contribute valuable information towards understanding the mechanisms controlling sediment and $\mathrm{P}$ loss. It can also provide an estimate of future losses due to climate change and potential losses at larger scales. Field-scale research offers a real-life situation where ground-truthing of laboratory findings can take place. At the catchment-scale, diffuse sediment losses can be traced from source to receptor using constantly improving techniques, such as sediment fingerprinting.

\section{ACKNOWLEDGEMENTS}

The first author acknowledges funding received under the Teagasc Walsh Fellowship scheme. The authors acknowledge Dermot Forristal, Teagasc, Oak Park and Mark Plunkett, Teagasc, Johnstown Castle for their helpful comments in the areas of tillage cropping and cultivation and nutrient management.

\section{REFERENCES}

Alakukku, L., Weisskopf, P., Chamen, W.C.T., Tijink, F.G.J., Van der Linden, J.P., Pires, S., Sommer, C. and Spoor, G. 2003 Prevention strategies for field traffic-induced subsoil compaction: a review. Part 1. Machine/soil interactions. Soil and Tillage Research 73, 145-60.

Andraski, B.J., Mueller, D.H. and Daniel, T.C. 1985 Phosphorus losses in runoff as affected by tillage. Soil Science Society of America Journal 49, 1523-7.

Arnold, J.G., Srinvasen, R., Muttiah, R.S. and Williams, J.R. 1998 Large area hydrological modelling and assessment Part I: model development. Journal of the American Water Resources Association 34, 73-89.

Barker, R., Dixon, L. and Hooke, J. 1997 Use of terrestrial photogrammetry for monitoring and measuring bank erosion. Earth Surface Processes and Landforms 22, 1217-27.

Bicknell, B.R., Imhoff, J.C., Donigian, A.S., Johanson, R.C. 1997 Hydrological simulation program - FORTRAN (HSPF), user's manual For Release 11. EPA - 600/R-97/080. United States Environmental Protection Agency, Athens, GA.

Blake, W.H., He, Q. and Walling, D.E. 1999 Fallout beryllium-7 as a tracer in soil erosion investigations. Applied radiation and Isotopes 51 (5), 599-605.

Boardman, J. 1990 Soil erosion on the South Downs: a review. In J. Boardman, I.D.L. Foster and J.A. Dearing (eds), Soil erosion on agricultural land, 87-105. Chichester. John Wiley.

Boardman, J., Shepheard, M.L., Walker, E. and Foster, I.D.L. 2009 Soil erosion and risk-assessment for on- and off-farm impacts: a test case using the Midhurst area, West Sussex, UK. Journal of Environmental Management 90, 2578-88.

Bowman, J. 2009 New Water Framework Directive environmental quality standards and biological and hydromorphological classification 
systems for surface waters in Ireland. Biology and Environment: Proceedings of the Royal Irish Academy 109B, 247-60.

Bundy, L.G., Andraski, T.W. and Powell, J.M. 2001 Management practice effects on phosphorus losses in runoff in Corn Production systems. Journal of Environmental Quality 30, 1822-8.

Carton, O., Coulter, B., Herlihy, M. and Hackett, R.A. 2002 Nutrient recommendations for tillage crops and their environmental implications. In National Tillage Conference 2002, Teagasc, Ireland. (Available at http://www.teagasc.ie/ publications/2002/nattillageconf/paper04.asp, accessed 8 December 2011.)

Catt, J.A., Howse, K.R., Farina, R., Brockie, D., Todd, A., Chambers, B.J., Hodgkinson, R., Harris, G.L. and Quinton, J.N. 1998 Phosphorus losses from arable land in England. Soil Use and Land Management 14, 168-74.

Cerdan, O., Govers, G., Le Bissonnais, Y., Van Oost, K., Poesen, J., Saby, N., Gobin, A., Vacca, A., Quinton, J., Auerswald, K., Klik, A., Kwaad, F., Raclot, D., Ionita, I., Rejman, J., Rousseva, S., Muxart, T., Roxo, M. and Dostal, T. 2006 Sheet and rill erosion. In Soil Erosion in Europe, Boardman J, Poesen J (eds). 501-13. Chichester. John Wiley \& Sons.

Chambers, B.J., Davies, D.B. and Holmes S. 1992 Monitoring of water erosion on arable farms in England and Wales, 1989-90. Soil Use and Management 8, 163-70.

Chambers, B.J. and Garwood, T.W.D. 2000 Monitoring of water erosion on arable farms in England and Wales 1990-94. Soil Use and Land Management 16, 93-9.

Chambers, B.J., Garwood, T.W.D. and Unwin, R.J. 2000 Controlling soil water erosion and phosphorus losses from arable land in England and Wales. Journal of Environmental Quality 29, 145-50.

Chamen, W.C.T., Alakukku, L., Pires, S., Sommer, C., Spoor, G., Tijink, F. and Weisskopf, P. 2003 Prevention strategies for field trafficinduced subsoil compaction. Part 2. Equipment and field practices. Soil and Tillage Research 73, 161-74.

CIAT 2004 Hole-filled Seamless SRTM Data V1. Cali. International Centre for Tropical Agriculture.

Collins, J.F. and T. Cummins 1996 Agroclimatic Atlas of Ireland. AGMET, c/o Met Éireann, Dublin.

Collins, A.L., Walling, D.E. and Leeks G.J.L. 1996 Composite fingerprinting of the spatial source of fluvial suspended sediment: a case study of the Exe and Severn River basins, United Kingdom. Geomorphology: Relief, Processes Environment 2, 41-54.

Collins, A.L., Walling, D.E. and Leeks, G.J.L. 1998 Use of composite fingerprints to determine the provenance of the contemporary suspended sediment loads transported by rivers. Earth Surface Processes and Landforms 23, 31-52.

Collins, A.L. and Walling, D.E. 2007 The storage and provenance of fine sediment on the channel bed of two contrasting lowland permeable catchment, UK. River Research and Applications 23, 429-50.

Commission of the European Communities 2006 COM(2006)231 Communication from the Commission to the Council, the European Parliament, the European Economic and Social Committee and the Committee of Regions - thematic strategy for soil protection. Commission of the European Communities, Brussels. (Available at: http://eur-lex.europa.eu/ LexUriServ/LexUriServ.do?uri=COM:2006: 0231:FIN:EN:PDF, accessed 21 January 2012).

Coulter, B.S. and Lalor, S. 2008 Major and micro nutrient advice for productive agricultural crops. $3 \mathrm{rd} \mathrm{ed}$. Teagasc, Johnstown Castle, Wexford.

Council of the European Union 1991 Council Directive 91/676/EEC of 21 May 1991 concerning the protection of waters against pollution caused by nitrates from agricultural sources. Official Journal of the European Communities L375, 1-8.

Council of the European Union 2000 Water Framework Directive 2000/60/EC establishing a framework for community action in the field of water policy, Council of the European Union.

Creamer, R.E., Brennan, F., Fenton, O., Healy, M.G., Lalor, S.T.J., Lanigan, G.J., Regan, J.T. and Griffiths B.S. 2010 Implications of the proposed Soil Framework Directive on agricultural systems in Atlantic Europe - a review. Journal of Soil Use and Management 26 (3), 198-211.

CSO 2010 Crops and Livestock Survey June 2009-Final Results, CSO. (Available at http:// www.cso.ie/en/media/csoie/releasespublications/documents/agriculture/current/ croplsfinal.pdf, accessed 23 January 2012.)

Culleton, N., Coulter, B. and Liebhardt, W.C. 2002 The fate of phosphatic fertiliser applied to grassland. Irish Geography 35, 175-84.

Curtin, J.S., and Mullen, G.J. 2007 Physical properties of some intensively cultivated soils of Ireland amended with spent mushroom compost. Land Degradation and Development 18, 355-68.

DAFF 2009a. Maintenance of soil organic matter, Department of Agriculture, Fisheries and Food, Dublin. (Available at http://www.agriculture. gov.ie/media/migration/farmingschemesandpayments/crosscompliance/soilorganicmatter/ Soil\%20 organic\%20matter\%20guidelines.pdf, accessed 8 December 2011.)

DAFF 2009b. Fertiliser consumption, 1989/20052007/2008. Department of Agriculture, Fisheries and Food, Dublin. (Available at http:// www.agriculture.gov.ie/media/migration/ publications $/ 2008 /$ compendium 2008/individual/H5.xls, accessed 8 December 2011.) 
Daly K. 1999 An environmental appraisal of the phosphorus dynamics of Irish grassland soils. Ph.D., Botany Department Trinity College, Dublin, Ireland.

Daly, K., Jeffrey, D. and Tunney, H. 2001 The effect of soil type on phosphorus sorption capacity and desorption dynamics in Irish grassland soils. Soil Use Management 17, 12-20.

Daly, K., Mills, P., Coulter, B. and McGarrigle, M. 2002 Modelling phosphorus concentrations in Irish rivers using land use, soil type and soil phosphorus data. Journal of Environmental Quality 31, 590-9.

Daverede, I.C., Kravchenko, A.N., Hoeft, R.G., Nafziger, E.D., Bullock, D.G., Warren, J.J. and Gonzini, L.C. 2003 Phosphorus runoff: Effect of tillage and soil phosphorus levels. Journal of Environmental Quality 32, 1436-44.

Deasy, C., Quinton, J.N., Silgram, M., Bailey, A.P., Jackson, B. and Stevens, C.J. 2009 Mitigation options for sediment and phosphorus loss from winter-sown arable crops. Journal of Environmental Quality 38, 2121-30.

Deasy, C., Quinton, J.N., Silgram, M., Bailey, A.P., Jackson, B. and Stevens, C.J. 2010 Contributing understanding of mitigation options for phosphorus and sediment to a review of the efficacy of contemporary agricultural stewardship measures. Agricultural Systems 103, 105-09.

Defra, 2005 Controlling Soil Erosion: a Manual for the Assessment and Management of Agricultural Land at Risk of Water Erosion in Lowland England. Revised September 2005a. London. Department for Environment, Food and Rural Affairs.

Defra, 2006 Single Payment Scheme: Cross compliance Guidance for Soil Management, 2006 ed. Rural Payments Agency and Department for Environment, Food and Rural Affairs, London.

Department of Agriculture \& Food, 2005 The single payment scheme. Guide to cross compliance, DAF. (Available at http://www.agriculture. gov.ie/media/migration/publications/2005/ singlefarmpay2005.pdf, accessed 8 December 2011.)

Doody, D., Moles, R., Tunney, H., Kurz, I., Bourke, B., Daly, K. and O'Regan, B. 2006 Impact of flow path length and flow rate on phosphorus loss in simulated overland flow from a humic gleysol grassland soil. Total Science of the Environment 372, 247-55.

Doody, D.G., Archbold, M., Foy, R.H. and Flynn, R. 2012 Approaches to the implementation of the Water Framework Directive: Targeting mitigation measures at critical source areas of diffuse phosphorus in Irish catchments. Journal of Environmental Management 93, 225-34.

Douglas, R.W., Menary, W. and Jordan, P. 2007 Phosphorus and sediment transfers in a grassland river catchment. Nutrient Cycling in Agroecosystems 77, 199-212.
Edwards, A.C. and Withers, P.J.A. 2008 Transport and delivery of suspended solids, nitrogen and phosphorus from various sources to freshwaters in the UK. Journal of Hydrology 350, 144-53.

EEA, 1995 Europe's Environment: the Dobris Assessment. European Environment Agency. (Available at http://www.eea.europa.eu/ publications/92-826-5409-5, accessed 8 December 2011.)

Ekstrand, S., Wallenberg, P. and Djodjic, F. 2010 Process based modelling of phosphorus losses from arable land. Ambio 39, 100-15.

EPA, 2009 Strive Annual Report 2009, Wexford; Environmental Protection Agency. (Available at http:// www.epa.ie/downloads/pubs/research/STRIVE_ AnnRpt09.pdf, accessed 8 December 2011.)

European Communities 2010. (Good agricultural practice for protection of waters) Regulations 2010. SI 610 of 2010. Department of Environment, Heritage and Local Government, The Stationary Office, Dublin.

Evans, D.J., Gibson, C.E. and Rossell, R.S. 2006 Sediment loads and sources in heavily modified Irish catchments: A move towards informed management strategies. Geomorphology 79, 93-113.

Ewen, J., Parkin, G. and O'Connell, E. 2000 SHETRAN: Distributed basin flow and transport modelling system. Journal of Hydrologic Engineering 5, 250-8.

Fang, F., Brezonik, P.L., Mulla, D.J. and Hatch L.K. 2002 Estimating runoff phosphorus losses from calcerous soils in Minnesota River basin. Journal of Environmental Quality 31, 1918-29.

Fay, D., McGrath, D., Chaosheng, Z., Carrigg, C., O'Flaherty, V., Carton, O.T. and Grennan, E. 2002 Towards a national soil database, Appendix E, Environmental RTDI Programme 2000-2006 (2001-CD/S2-M2). Wexford. Environmental Protection Agency.

Fay, D., Kramers, G., Zhang, C., McGrath, D. and Grennan, E. 2007 Soil Geochemical Atlas of Ireland. Wexford; Environmental Protection Agency. (Available at http://erc.epa.ie/safer/ iso19115/displayISO19115.jsp ? isoID $=105$, accessed 8 December 2011.)

Fealy, R.M., Buckley, C., Mechan, S., Melland, A., Mellander, P.E., Shortle, G., Wall, D. and Jordan, P. 2010 The Irish agricultural catchments programme: catchment selection using spatial multi-criteria decision analysis. Soil Use and Management 26, 225-36.

Fernandez, C., Wu, J.Q., McCool, D.K. and Stöckle, C.O. 2003 Estimating water erosion and sediment yield with GIS, RUSLE, and SEDD. Journal of Soil Water Conservation 58, 128-36.

Forristal, D. and Murphy, K. 2009 Can we reduce costs and increase profits with Min Till? In National Tillage Conference proceedings 2009, 48-67, Crops Research Centre, Teagasc, Oak 
Park, Carlow, Ireland. (Available at http:// www.teagasc.ie/publications/2009/20090130/ NTCProceedings2009.pdf, accessed 8 December 2011.)

Franklin D., Truman, C., Potter, T., Bosch, D., Strickland, T. and Bednarz, C. 2007 Nitrogen and phosphorus runoff losses from variable and constant intensity rainfall simulations on loamy sand under conventional and strip tillage systems. Journal of Environmental Quality 36, 846-54.

Fraser, A.I., Harrod, T.R. and Haygarth, P.M. 1999 The effect of rainfall intensity on soil erosion and particulate phosphorus transfer from arable soils. Water Science and Technology 39, 41-5.

Fu, G., Chen, S. and McCool, D.K. 2006 Modelling the impacts of no-till practice on soil erosion and sediment yield with RUSLE, SEDD and ArcView GIS. Soil and Tillage Research 85, 38-49.

Fullen, M.A. 1991 A comparison of runoff and erosion rates on bare and grassed loamy sand soils. Soil Use and Management 7 (3), 136-9.

Fullen, M.A. 1998 Effects of grass ley set-aside on runoff, erosion and organic matter levels in sandy soils in east Shropshire, UK. Soil and Tillage Research 46, 41-9.

Fullen, M.A. 2003 Soil erosion and conservation in northern Europe. Progress in Physical Geography 27, 331-58.

Fullen, M.A., Arnalds, A., Bazzoffi, P., Booth, C.A., Castillo, V., Kertész, Á., Martin, P., Ritsema, C., Benet, A.S., Souchére, V., Vandekerckhove, L. and Verstraeten, G. 2006 Government and agency response to soil erosion risk in Europe. In J. Boardman and J. Poesen (eds), Soil erosion in Europe, 805-26. Chichester. John Wiley.

Gardiner, M.J. and Radford, T. 1980 Soil associations of Ireland and their land use potential: Explanatory Bulletin to soil map or Ireland 1980. National Soil Survey of Ireland. Ireland. An Foras Talúntais.

Gburek, W. and Sharpley, A.N. 1998 Hydrologic controls on phosphorus loss from upland agricultural watersheds. Journal of Environmental Quality 27, 267-77.

Gentry, L.E., David, M.B., Royer, T.V., Mitchell, C.A. and Starks, K.M. 2007 Phosphorus transport pathways to streams in tile-drained agricultural watersheds. Journal of Environmental Quality 36, 408-15.

Hackett, R., Spink, J., Forristal, D. and Creamer, R. 2010 Impact of management practices on soil organic carbon levels under Irish conditions. In National Tillage Conference proceedings 2010, 77-91, Oak Park, Carlow, Ireland. Crops Research Centre.

Hart, M.R., Quin, B.F. and Nguyen, M.L. 2004 Phosphorus runoff from agricultural land and direct fertilizer effects: A review. Journal of Environmental Quality 33, 1954-72.

Haygarth, P.M. and Jarvis, S.C. 1997 Soil derived phosphorus in surface runoff from grazed grassland lysimeters. Water Research 31, 140-8.
Haygarth, P.M. and Jarvis, S.C. 1999 Transfer of phosphorus from agricultural soils. Advances in Agronomy 66, 195-249.

Haygarth, P.M., Condron, L.M., Heathwaite, A.L., Turner, B.L. and Harris, G.P. 2005 The phosphorus transfer continuum: Linking source to impact with an interdisciplinary and multiscaled approach. Science of the Total Environment 344, 5-14.

He, Y. 2010 Estimating soil erosion and sediment yield with GIS, RUSLE and SEDD: a case study in Ireland. Unpublished Masters thesis, School of Geography and Archaeology, National University of Ireland, Galway.

Hooker, K.V., Coxon, C.E., Hackett, R., Kirwan, L.E., O'Keeffe, E. and Richards, K.G. 2008 Evaluation of cover crop and reduced cultivation for reducing nitrate leaching in Ireland. Journal of environmental Quality 37, 138-45.

Hughes, K.J., Magette, W.L. and Kurz, I. 2005 Identifying critical source areas for phosphorus loss in Ireland using field and catchment scale ranking schemes. Journal of Hydrology 304, 430-45.

Im, S., Brannan, K., Mostaghimi, S. and Cho, J. 2003 A comparison of SWAT and HSPF models for simulating hydrologic and water quality responses from an urbanizing watershed. ASAE Paper no. 032175. 27-30 June 2003, Las Vegas, USA, ASAE Annual International Meeting.

Irvine, K., Allott, A., De Eyto, E., Free, G., White, J., Caroni, R., Kennelly, C., Keany, J., Lennon, C., Kemp, A., Barry, E., Day, S., Mills, P., O’Ríain, G., Quirke, B., Twomey H. and Sweeney, P. 2001 Ecological assessment of Irish lakes - final report. Wexford. EPA.

Irvine, K., Mills, P., Bruen, M., Walley, W., Hartnett, M., Black, A., Tynan, S., Duck, R., Bragg, O., Rowen, J., Wilson, J., Johnston, P. and O'Toole, C. 2005 Water framework directive-an assessment of mathematical modelling in its implementation in Ireland. Teagasc, Johnstown Castle, Co, Wexford, Ireland.

Jordan, C., McGuckin, S.O. and Smith, R.V. 2000 Increased predicted losses of phosphorus to surface waters from soils with high Olsen-P concentrations. Soil Use and Management 16, 27-35.

Jordan, P., Menary, W., Daly, K., Kiely, G., Morgan, G., Byrne, P. and Moles, R. 2005a Patterns and processes of phosphorus transfer from Irish grassland soils to rivers-integration of laboratory and catchment studies. Journal of Hydrology 304, 20-34.

Jordan, P., Arnssheidt, J., McGrogan, H. and McCormick, S. 2005b High-resolution phosphorus transfers at the catchment scale: the hidden importance of non-storm transfers. Hydrology and Earth System Sciences 9, 685-91. 
Jordan, P., Arnssheidt, J., McGrogan, H. and McCormick, S. 2007 Characterising phosphorus transfers in rural catchments using a continuous bank-side analyser. Hydrology and Earth System Sciences 11, 372-81.

Kiely, G. 2000 Hydrometeorological aspects of farm in Dripsey Catchment (NMP). In H. Tunney (ed), Quantification of phosphorus loss from soil to water, 38-50. Wexford. EPA.

Knappen, A., Poesen, J., Govers, G. and De Baets, S. 2008 The effect of conservation tillage on runoff erosivity and soil erodibility during concentrated flow. Hydrological Processes 22, 1497-508.

Koskiaho, J., Kallio, K. and Puustinen, M. 2002 Reduced tillage: influence on erosion and nutrient losses in a clayey field in southern Finland. Agricultural and Food Science of Finland, 11, 37-50.

Krause, S., Jacob, J., Voss, A., Bronstert, A. and Zehe, E. 2008 Assessing the impact of changes in landuse and management practices on the diffuse pollution and retention of nitrate in a riparian floodplain. Science of the Total Environment 389, 149-64.

Kronvang, B., Laubel, A. and Grant, R. 1997 Suspended sediment and particulate phosphorus transport and delivery pathways in an arable catchment, Gelbaek stream, Denmark. Hydrological Processes 11, 627-42.

Kronvang, B., Bechmann, M., Lundekvam, H., Behrendt, H., Rubaek, G.H., Schoumans, O.F., Syversen, N., Andersen, H.E. and Hoffmann C.C. 2005 Phosphorus losses from agricultural areas in river basins: Effects and uncertainties of targeted mitigation measures. Journal of Environmental Quality 34, 2129-44.

Kurz, I., 2000. Phosphorus exports from agricultural grassland with overland flow and drainage water (Johnstown Castle). In H. Tunney (ed), Quantification of Phosphorus Loss from Soil to Water, 14-23. Wexford. EPA.

Kurz, I., Coxon, C., Tunney, H. and Ryan, D. 2005 Effects of grassland management practices and environmental conditions on nutrient concentrations in overland flow. Journal of Hydrology 304, 35-50.

Kurz, I., O'Reilly, C. and Tunney, H. 2006 Impact of cattle on soil physical properties and nutrient concentrations in overland flow from pasture in Ireland. Agriculture, Ecosystems and Environment 113, 378-90.

Lal. R. 2001 Soil degradation by erosion. Land Degradation \& Development 12, 519-39.

Lalor, S.T.J., Coulter, B.S., Quinlan, G. and Connolly, L. 2010 A survey of fertilizer use in Ireland from 2004-2008 for grassland and arable crops. Johnstown Castle Research Centre, Teagasc, Wexford, Ireland. (Available at http://www. teagasc.ie/publications/2010/13/13_Fert_Use_
Survey_2008-Final.pdf, accessed 8 December 2011.)

Lao, Y.Z. and Coote, D.R. 1993 Topography and water erosion in Northern Shanxi Province, China. Geoderma 59, 249-62.

Lawler, D.M., Thorne, C.R. and Hooke, J.M. 1997 Bank erosion and instability. In C.R. Thorne, R.D. Hey and M.D. Newson (eds), Applied fluvial geomorphology for river engineering and management, 137-72. Chichester. John Wiley.

Lennox, S.D., Foy, R.H., Smith, R.V. and Jordan, C. 1997 Estimating the contribution from agriculture to the phosphorus load in surface waters. In H. Tunney, O.T. Carton, P.C. Brooks and A.E. Johnson (eds), Phosphorus loss from soil to water, 77-94. Wallingford. UK. C.A.B.

Lewis, C. 2003 Phosphorus, nitrogen and suspended sediment loss from soil to water from agricultural grassland. Masters thesis, department of Civil and Environmental Engineering, University College Cork.

Lindstrom, M.J., Lobb, D.A. and Schumacher, T.E. 2001 Tillage erosion: an overview. Annals of Arid Zone 40, 337-49.

Little, J.L., Bennett, D.R. and Miller, J.J. 2005 Nutrient and sediment losses under simulated rainfall following manure incorporation by different methods. Journal of Environmental Quality 34, 1883-95.

Lowe, S.A. 2006 Discussion of "HSPF simulation of runoff and sediment loads in the Upper Changjiang River basin, China" by Seiji Hayashi, Shogo Murakami, Masataka Watanabe, and Xu Bao-Hua. Journal of Environmental Engineering 132, 145-7.

Lucey, J. (ed.) 2009 Water Quality in Ireland 2007 2008: Key Indicators of the Aquatic Environment. Co. Wexford. Teagasc.

Marsili, A. and Servadio, P. 1996 Compaction effects of rubber or metal-tracked tractor passes on agricultural soils. Soil and Tillage Research 37, 37-45.

McElwain, L. and Sweeney J. 2006 Key meteorological indicators of climate change in Ireland. Wexford. EPA.

McGarrigle, M.L. and Donnelley, K. 2003 Phosphorus loading from a rural catchment River Deel, County Mayo, Ireland - a tributary of Lough Conn. In Proceedings, diffuse pollution conference Dublin 2003, 1D 1, 80-6. (Available at http:// www.ucd.ie/dipcon/docs/theme01/theme01_15. pdf, accessed 8 December 2011.)

McGarrigle, M., Lucey, J. and Ó Cinnéide, M. 2010 Water Quality in Ireland 20072009. Co. Wexford; Environmental Protection Agency. (Available at http://www.epa.ie/downloads/pubs/water/waterqua/WaterQuality0709. pdf, accessed 8 December 2011.)

McGrath, D., Carton, O.T., Diamond, S., O'Sullivan, A.M., Murphy, W.E., Rogers, P.A.M., Parle, P.J. 
and Byrne, E. 2001 Soil, herbage, feed and water. In: Investigation of animal health problems at Askeaton, Co. Limerick. Johnstown Castle Estate, Wexford: Teagasc.

Merritt, W.S., Letcher, R.A. and Jakeman, A.J. 2003 A review of erosion and sediment transport models. Environmental Modelling and Software 18, 761-99.

Met Éireann 2012 (Available at: http://www. met.ie/climate-ireland/rainfall.asp, accessed 24 January 2012).

Miller, N. and Quinton, J.N. 2009 Variability in the mobilization of sediment and phosphorus across 13 European soils. Journal of Environmental Quality 38, 742-50.

Montesinos-Barrios, P. and Beven, K. 2001 Evaluation of TOPMODEL. In J.E. Parsons, D.L. Thomas and R.L. Huffman (eds.), Nonpoint source water quality models: Their use and application, 149-55. Southern Cooperative Series Bulletin \#398, ISBN: 1-58161-398-9. (Available at: http://s1004.okstate.edu/S1004/RegionalBulletins/Modeling-Bulletin/modeling-bulletin. pdf, accessed 21 January 2012).

Montgomery, D. 2007 Dirt: the erosion of civilisation. Berkeley, CA. University of California Press.

Morgan, G., Xie, Q. and Devins, M. 2000 Phosphorus export from farm in Dripseycatchment, Co. Cork. In H. Tunney (ed), Quantification of phosphorus loss from soil to water, 24-37. Wexford. EPA.

Murphy, P.N.C. 2007 Lime and cow slurry application temporarily increases organic phosphorus mobility in an acidic soil. European Journal of Soil Science, 58, 794-801.

Murphy, P.N.C. and Stevens, R.J. 2010 Lime and gypsum as source measures to decrease phosphorus loss from soils to water. Water, Air, and Soil Pollution, 212, 101-11.

Nasr, A., Taskinein, A. and Bruen, M. 2005 Developing an independent, generic, phosphorus modelling component for use with grid-oriented, physically based distributed catchment models. Water Science and Technology 51, 135-42.

Nasr, A., Bruen, M., Jordan, P., Moles, R., Kiely, G. and Byrne, P. 2007 A comparison of SWAT, HSPF and SHETRAN/GOPC for modelling phosphorus export from three catchments in Ireland. Water Research 41, 1065-73.

Pionke, H.B., Gburek, W.J., Sharpley, A.N. and Zollweg, J.A. 1997 Hydrological and chemical controls on phosphorus loss from catchments. In H. Tunney, O.T. Carton, P.C. Brooks and A.E. Johnson (eds), Phosphorus losses from soil to water, 77-94. Wallingford, UK. C.A.B.

Peech, M. and English, L. 1944 Rapid microbiological soil tests. Soil Science 57, 167-94.

Pote, D.H., Daniel, T.C., Nichols, D.J., Sharpley, A.N., Moore, Jr., P.A. Miller, D.M. and Edwards, D.R. 1999 Relationship between phosphorus levels in three ultisols and phosphorus concentrations in runoff. Journal of Environmental Quality 28, $170-5$.

Potter, T.L., Truman, C.C., Bosch, D.D., Strickland, T.C., Franklin, D.H., Bednarz, C.W. and Webster, T.M. 2006 Effect of constant versus variable intensity simulated rainfall on cotton preemergence herbicide runoff. Journal of Environmental Quality 35, 1894-902.

Quinton, J.N., Catt, J.A., and Hess, T.M. 2001 The selective removal of phosphorus from soil: is event size important? Journal of Environmental Quality 30, 538-45.

Quinton, J.N. and Catt, J.A. 2004 The effects of minimal tillage and contour cultivation on surface runoff, soil loss and crop yield in the longterm Woburn Erosion Reference Experiment on sandy soil at Woburn, England. Soil Use and Land Management 20, 343-9.

Quinton, J.N., Govers, G., Van Oost, K. and Bardgett, R.D. 2010 The impact of agricultural soil erosion on biogeochemical cycling. Nature Geoscience 3, 311-4.

Regan, J.T., Rodgers, M., Healy, M.G., Kirwan, L. and Fenton, O. 2010 Determining phosphorus and sediment release rates from five Irish tillage soils. Journal of Environmental Quality 39, 185-92.

Renard, K.G., Foster, G.R., Weesies, G.A. and Porter, J.P. 1991 RUSLE: revised universal soil loss equation. Journal of Soil and Water Conservation 46, 30-33.

Renard, K.G., Foster, G.R., Yoder, D.C., McCool, D.K., 1994 RUSLE revisited: status, questions, answers, and the future. Journal of Soil and Water Conservation 49, 213- 20.

Robinson, D.A. 1999 Agricultural practice, climate change and the soil erosion hazard in parts of southeast England. Applied Geography 19, 13-27.

Scanlon, T.M., Kiely, G. and Xie, Q. 2004 A nested catchment approach for defining the hydrological controls on non-point phosphorus transport. Journal of Hydrology 291, 218-31.

Scanlon, T.M., Kiely, G. and Xie, Q. 2005 Model determination of non-point source phosphorus transport pathways in a fertilized grassland catchment. Hydrological Processes 19, 2801-14.

Schroeder, P.D., Radcliffe, D.E., Cabrera, M.L. and Belew, C.D. 2004 Relationship between soil test phosphorus and phosphorus in runoff: Effects of soil series variability. Journal of Environmental Quality 33, 1452-63.

Schuller, P., Walling, D.E., Sepulveda, A., Trumper, R.E., Rouanet, J.L., Pino, I. and Castillo A. 2004 Use of ${ }^{137} \mathrm{Cs}$ measurements to estimate changes in soil erosion rates associated with changes in soil management practices on cultivated land. Applied Radiation and Isotopes $\mathbf{6 0}$, 759-66.

Schulte, R.P.O., Richards, K., Daly, K., Kurz, I., McDonald, E.J. and Holden, 
N.M. 2006a Agriculture, meteorology and water quality in Ireland: a regional evaluation of pressures and pathways of nutrient loss to water. Biology and Environment: Proceedings of the Royal Irish Academy 106B, 117-33.

Schulte, R.P.O. 2006b Modelling phosphorus for grassland: agronomically and environmentally sustainable advice. Teagasc; Johnstown Castle Research Centre, Wexford. (Available at http://www. teagasc.ie/research/reports/environment/5188/ eopr-5188.pdf, accessed 8 December 2011.)

Schulte, R.P.O., Melland, A., Fenton, O., Herlihy, M., Richards, K. and Jordan, P. 2010a Modelling soil phosphorus decline: Expectations of Water Framework Directive policies. Environmental Science and Policy 13, 472-84.

Schulte, R.P.O., Gibson, M.T., Lalor S.T.J. and Hackett R. 2010b Independent review of the science, implementation and administration of the Draft European Communities (Good Agricultural Practice for the Protection of Waters) regulations 2010 with associated proposals for amendments, Agriculture and Food Development Authority. Teagasc; Johnstown Castle Research Centre, Wexford. (Available at http://www.teagasc.ie/publications/2010/981/ TeagascReviewDraftGAPRegulations2010.pdf, accessed 8 December 2011.)

Sepulveda, A., Schuller, P., Walling, D.E. and Castillo, A. 2008 Use of ${ }^{7} \mathrm{Be}$ to document soil erosion associated with a short period of extreme rainfall. Journal of Environmental Radioactivity 99, 35-49.

Sharpley, A.N. and Smith, S.J. 1990 Phosphorus transport in agricultural runoff: The role of soil erosion. In J. Boardman, I.D.L. Foster and J.A. Dearing (eds), Soil erosion on agricultural land, 351-66. Chichester. John Wiley.

Sharpley, A.N. 1993 Assessing phosphorus bioavailability in agricultural soils and runoff. Fertilizer Research 36, 259-72.

Sharpley, A.N., Hedley, M.J., Sibbesen, E., HillbrichtIlkowska, A., Alan House, W. and Ryszkowski, L. 1995 Phosphorus transfers from terrestrial to aquatic ecosystems. In H. Tiessen (ed), Phosphorus in the global environment: transfers, cycles and management. 171-200. New York. John Wiley and Sons.

Sharpley, A.N. and Rekolainen, S. 1997 Phosphorus in agriculture and its environmental implications. In H. Tunney, O.T. Carton, P.C. Brooks and A.E. Johnson (eds), Phosphorus losses from soil to water, 1-53. Wallingford. UK. C.A.B.

Sharpley, A.N., McDowell, R.W. and Kleinman, P.J.A. 2001a Phosphorus loss from land to water: integrating agricultural and environmental management. Plant and Soil 237, 287-307.

Sharpley, A.N., McDowell, R.W., Weld, J.L. and Kleinman, P.J.A. 2001b Assessing site vulnerability to phosphorus loss in an agricultural watershed. Journal of Environmental Quality 30, 2026-36.

Sibbesen, E. and A.N. Sharpley. 1997 Setting and justifying upper critical limits for P in soils. In H. Tunney, O.T. Carton, P.C. Brooks and A.E. Johnson (eds), Phosphorus losses from soil to water, 151-76. Wallingford, UK. C.A.B.

Silgram, M., Jackson, D.R., Bailey, A., Quinton, J. and Stevens, C. 2010 Hillslope scale surface runoff, sediment and nutrient losses associated with tramline wheelings. Earth Surface Processes and Landforms 35, 699-706.

Sims, J.T., Simard, R.R. and Joern, B.C. 1998 Phosphorus loss in agricultural drainage: historical perspective and current research. Journal of Environmental Quality 27, 277-93.

Sims, J.T., Maguire, R.O., Leytem, A.B. Gartley, K.L. and Pautler, M.C. 2002 Evaluation of Mehlich 3 as an agri-environmental soil phosphorus test for the Mid-Atlantic United States of America. Soil Science Society of America Journal 66, 2016-32.

Smith, R.V., Lennox, S.D., Jordan, C., Foy, R.H. and McHale, E. 1995 Increase in soluble phosphorus transported in drainflow from a grassland catchment in response to soil phosphorus accumulation. Soil Use and Management 11, 204-9.

Smith, R.V., Jordan, C. and Annett, J.A. 2005 A Phosphorus budget for Northern Ireland; inputs to inland and coastal waters. Journal of Hydrology 304, 193-202.

Søndergaard, M., Jensen, J.P. and Jeppesen, E. 2001 Retention and internal loading of phosphorus in shallow, eutrophic lakes. The Scientific World 1, 427-42.

Speirs, R.B. and Frost, C.A. 1987 Soil water erosion on arable land in the United Kingdom. Research and Development in Agriculture 4, 1-11.

Spink, J., Hackett, R., Forristal, D. and Creamer, R. 2010 Soil Organic Carbon: A review of 'critical' levels and practices to increase levels in tillage land in Ireland. Teagasc, Oak Park Crops Research Centre, Co. Carlow. (Available at: http://www.teagasc.ie/publications/2010/982/ SoilOrganicCarbon.pdf, 8 December 2011.)

Steinman, A.D. and Ogdahl, M. 2008 Ecological effects after an alum treatment in Spring Lake, Michigan. Journal of Environmental Quality 37, 22-9.

Stevens, C.J., Quinton, J.N., Bailey, A.P., Deasy, C., Silgram, M. and Jackson, D.R. 2009 The effects of minimal tillage, contour cultivation and in-field vegetative barriers on soil erosion and phosphorus loss. Soil and Tillage Research 106, 145-51.

Sweeney, J., Albanito, F., Brereton, A., Caffarra, A., Charlton, R., Donnelly, A., Fealy, R., Fitzgerald, J., Holden, N., Jones M. and Murphy, C. 2008 Climate change - refining the impacts for Ireland. Wexford. EPA. 
Tarkalson, D.D., and Mikkelsen, R.L. 2004 Runoff phosphorus losses as related to phosphorus source, application method, and application rate on a Piedmont soil. Journal of Environmental Quality 33, 1424-30.

Theis, T.L. and McCabe, P.J. 1978 Phosphorus dynamics in hypereutrophic lake sediments. Water Research 12, 677-85.

Toy, T.J., Foster, G.R. and Renard, K.G. 2002 Soil erosion: Processes, prediction, measurement, and control. New York. John Wiley and Sons.

Truman, C.C., Strickland, T.C., Potter, T.L., Franklin, D.H., Bosch, D.D. and Bednarz, C.W. 2007 Variable rainfall intensity and tillage effects on runoff, sediment, and carbon loss from loamy sand under simulated rainfall. Journal of Environmental Quality 36, 1495-502.

Tunney, H., Coulter, B., Daly, K., Kurz, I., Coxon, C., Jeffrey, D., Mills, P., Kiely, G. and Morgan, G. 2000 Quantification of phosphorus loss from soil to water, Agriculture and Food Development Authority. (Available at http://www.teagasc.ie/ research/reports/environment/4365/eopr-4365. pdf, 8 December 2011.)

Tunney, H., Kurz, I., Bourke, D., O’Reilly, C., Jeffrey, D., Dowding, P., Foy, B., Kilpatrick, D. and Haygarth, P. 2007 Eutrophication from agricultural sources: The impact of the grazing animal on phosphorus, nitrogen, potassium and suspended solids loss from grazed pastures - field-plot study. Wexford. EPA.

Udeigwe, T.K. and Wang, J.J. 2007 Predicting runoff of suspended solids and particulate phosphorus for selected Louisiana soils using simple soil tests. Journal of Environmental Quality 36, 1310-7.

Ulén B., Kronvang, B. and Svendson, L.M. 1991 Loss of phosphorus from woodland, natural land, and agricultural land. In Phosphorus in the Nordic Countries - Methods, Bioavailability, Effects and Measures. Nord 47, 83-100.

Ulén, B. and Jakobsson, C. 2005 Critical evaluation of measures to mitigate phosphorus losses from agricultural land to surface waters in Sweden. Science of the Total Environment 344, 37-50.

Ulén, B., Aronsson, H., Bechmann, M., Krogstad, T., Øygarden, L. and Stenberg, M. 2010 Soil tillage methods to control phosphorus loss and potential side effects: a Scandinavian review. Soil Use and Management 26, 94-107.

Van den Akker, J.J.H. and Canarache, A. 2000 Concerted actions on subsoil compaction in Western European countries and on subsoil compaction in Central and Eastern European countries. In J. Arvidsson, J.J.H. van den Akker and R. Horn (eds), Proceedings of the third workshop of the Concerted Action "Experience with the impact of subsoil compaction on soil, crop growth and environment and ways to prevent subsoil compaction",
7-19. Report 100, Division of Soil Management, Department of Soil Sciences, Swedish University of Agricultural Sciences, Uppsala, Sweden.

Van den Akker, J.J.H., Arvidsson, J. and Horn, R. 2003 Introduction to the special issue on experiences with the impact and prevention of subsoil compaction in the European Union. Soil and Tillage Research 73, 1-8.

Van Oost, K., Govers, G., De Alba, S. and Quine, T.A. 2006 Tillage erosion: a review of controlling factors and implications for soil quality. Progress in Physical Geography 30, 443-66.

Van Oost, K., Cerdan, O. and Quine, T.A. 2009 Accelerated sediment fluxes by water and tillage erosion on European agricultural land. Earth Surface Processes and Landforms 34, 1625-34.

Verstraeten G. and Poesen, J. $2001 \quad$ Factors controlling sediment yield from small intensively cultivated catchments in a temperate humid climate. Geomorphology 40, 123-44.

Vrieling, A. 2006 Satellite remote sensing for water erosion assessment: a review. Catena $\mathbf{6 5}$, 2-18.

Walling, D.E., Russell, M.A., Hodgkinson, R.A. and Zhang, Y. 2002 Establishing sediment budgets for two small lowland agricultural catchments in the UK. Catena 47, 323-53.

Walling, D.E., Collins, A.L., Jones, P.A., Leeks, G.J.L. and Old, G. 2006 Establishing fine-grained sediment budgets for the Pang and Lambourn LOCAR catchments, UK. Journal of Hydrology 330, 126-41.

Walter, M.T., Walter, M.F., Brooks, E.S., Steenhuis, T.S., Boll, J. and Weiler, K.R. 2000 Hydrologically Sensitive Areas: Variable Source Area Hydrology Implications for Water Quality Risk Assessment. Journal of Soil Water Conservation 3, 277-84.

Whiting, P.J., Bonniwell, E.C. and Matisoff, G. 2001 Depth and areal extent of sheet and rill erosion based on radionuclides in soils and suspended sediment. Geology 29, 1131-4.

Winegardner, D. 1996 An introduction to soils for environmental professionals. New York. Lewis Publishers.

Wischmeier, W.H. and Smith, D.D. 1978 Predicting soil erosion losses: A guide to conservation planning. USDA Agricultural Handbook No. 537. USA. USDA.

Withers, P.J.A. 1999 Cycling and sources of phosphorous in agricultural systems and to the wider environment: a UK perspective. In B.P. Weidema and M.J.G. Meeusen (eds), Agricultural data for life cycle assessments. 13-24. The Hague, Agricultural Economics Research Institute, The Netherlands.

Withers, P.J.A. and Hodgkinson, R.A. 2009 The effect of farming practices on phosphorus transfer to a headwater stream in England. Agriculture, Ecosystems and Environment 131, 347-55. 
Wright, C.R., Amrani, M., Akbar, M.A., Heaney, D.J. and Vanderwel, D.S. 2006 Determining phosphorus release rates to runoff from selected Alberta soils using laboratory rainfall simulation. Journal of Environmental Quality 35, 806-14.

Zhang, C., Fay, D., McGrath, D., Grennan, E. and Carton, O.T. 2008 Use of trans-Gaussian kriging for national soil geochemical mapping in Ireland. Geochemistry: Exploration, Environment, Analysis 8, 255-65.

Zhao, S.L., Gupta, S.C., Huggins, D.R. and Moncrief, J.F. 2001 Tillage and nutrient source effects on surface and subsurface water quality at corn planting. Journal of Environmental Quality 30, 998-1008. 